Article

\title{
The Bibliometric Keywords Network Analysis of Human Resource Management Research Trends: The Case of Human Resource Management Journals in South Korea
}

\author{
Chungil Chae ${ }^{1}$, Jeong-Ha Yim ${ }^{2}$, Jaeeun Lee ${ }^{3} \mathbb{C}$, Sung Jun Jo ${ }^{4}\left(\mathbb{D}\right.$ and Jeong Rok $\mathrm{Oh}^{5, *}$ \\ 1 College of Business and Public Management (CBPM), Kean University (Wenzhou), Wenzhou 325060, China; \\ cchae@kean.edu \\ 2 Department of Lifelong Education, Administration, and Policy, University of Georgia, \\ Athens, GA 30602, USA; jeinah@uga.edu \\ 3 Department of Adult Learning and Counselling, Sangji University, Wonju 26339, Korea; jelee@sangji.ac.kr \\ 4 Department of Global Business, Gachon University, Seongnam 13120, Korea; sungguri@gachon.ac.kr \\ 5 Graduate School of Public Administration, Korea University, Sejong 30019, Korea \\ * Correspondence: jroh58@korea.ac.kr; Tel.: +82-44-860-1547
}

Received: 19 June 2020; Accepted: 9 July 2020; Published: 15 July 2020

\begin{abstract}
Although previous studies on human resource management (HRM) research trends in the global context provided very useful information about the structures of HRM research trends, they have critical limitations. Despite the growing contribution and significance of HRM practices in Korea, a dominant group of scholars has rarely focused on what is going on in the research community in the country. To overcome the limitations and fill the gaps found in studies on the global HRM trends, the purpose of this study is to conduct the keyword network analysis investigating the semantic network structure composed of Korean HRM studies. A total of 1158 research papers published by three top peer-reviewed HRM journals in Korea that were published from 2007 to 2018 were analyzed. The result shows that the whole network structure of Korean HRM has a complex semantic structure that is socially constructed. Additionally, this study identified the top 10 prominent keywords and its ego-centric networks, and nine thematic clusters. By adopting keywords network analysis in bibliometric methods, this study provides an accurate structural interpretation of Korean HRM research practice to facilitate the sustainable development of the studies on the global HRM trends.
\end{abstract}

Keywords: human resource management (HRM); research trends; keyword network; bibliometrics; South Korea

\section{Introduction}

South Korea (hereafter Korea) is a country that has achieved unprecedented rapid economic development by the power of human resources. Korea, which lacks natural resources, was forced to rely on human resources for its economic development. Thus, human resource management (HRM) has received much attention from researchers in the country. HRM research on South Korea has been very active in the global arena. The International Journal of Human Resource Management (IJHRM) published a special edition about Korean HRM practices in 2013, and the quantity and quality of published papers in international journals authored by Korean authors have both been rising (e.g., References [1-3]).

Research performed by scholars has extended to dealing with more complex organizational issues as social phenomena that are related to HRM have become more sophisticated and connected with 
each other in Korea [4]. Accumulated research in a scientific discipline formed a semantic structure that reflects the socially shared, common research interests, themes, and concepts $[5,6]$. This semantic structure can be used as a lens to interpret the field-related concepts or phenomena in which the intellectual community has interests [7].

Investigating the semantic structure is an effective way for scholars to acquire information about what has been studied and how the topics of study were related to each other. Studies on semantic structure, including conceptual research papers, systematic literature reviews, and research trend studies might provide a synthesis of research findings, information about current or cumulated research trends, and guidance for future research and implications for practice [8-10]. Science mapping by using bibliometric methods helps researchers quickly grasp the research structure within a field of study and provides rigorousness into traditional literature reviews [7]. In recent research trend studies, bibliometrics has been applied for identifying a country-specific research trend or mapping a specific field of study and subject [6], and revealing evolutionary characteristics of discipline's development [11,12]. A relational approach to research trends is based on social constructivist theories [5,13-15]. The scholarly communication in a scientific discipline generates a collective knowledge and forms a semantic structure that represents research themes and discipline-specific shared terms [7].

Although globalization has become an inevitable wave in the scholarly community, publications on local trends of HRM research across the world have been far from sufficient. Exclusion of local research trends could lead to biased results in the global research context. As [9] argued, "narrow, disconnected, and incomplete views of the HRM field can limit scholars' ability to detect research opportunities" (p. 367). Existing studies in HRM bibliometric studies have focused little attention on outside the country. To catch up with the rapid trend of the globalization of business practices, the domains of research interest need to expand and broaden the research horizons to include local trends across the world.

As an effort toward the completeness of research on global research trends, we conducted a keyword network analysis of HRM research in Korea. Despite the growing contribution and significance of HRM practices in Korea, a dominant group of scholars has rarely focused on what is going on in the research community in the country. A study on Korean HRM research, which possesses both universality and uniqueness, can provide an opportunity to mitigate the limitations of mainstream HRM research. Korea is an interesting object of study because HRM practices in South Korea have been developed along with westernization, but the legacies of Eastern culture of Confucian tradition still remain strong. Bibliometric investigation on the intellectual and semantic structure of Korean HRM research can help scholars understand its ambivalence between global and local attributes. What can be found through this "country-specific" ([9], p. 382) study, especially through its specificity, might enable a comparison of Korea's HRM research trend with the global research trend and find some implications to the research and practices not only of Korea's HRM, but also of the global HRM community. Such a depth of understanding will also expand the scope of HRM research by deepening an understanding of HRM in a global context.

To overcome the limitations and fill the gaps found in studies on the global HRM trends, we conducted this keyword analysis investigating the semantic network structure composed of Korean HRM studies. Specifically, we would answer to following questions with this study.

1. What topics and keywords have been interested in and studied among researchers in Korea?

2. What theoretical and practical implications can be drawn from the uniqueness and universality of Korean HRM research?

3. How can the investigation of the "country-specific" semantic structure of Korean HRM contribute to improving HRM research at the global level? 


\section{Literature Review}

To conduct the literature review, the following procedure was used to identify previous studies on HRM research trends in the global and Korean contexts. First, following the specific criteria of the method used by Reference [9], this study covers all journals in business administration published until April 2019 in the Web of Science (WoS) database and the Korean Citation Index (KCI) database. Second, using field-related (i.e., human resource(s), human resource(s) management, personnel manage(ment), HR, and HRM) and subject-related (e.g., trend, direction, and review) search terms, we identified the pool of initial relevant articles. Third, the authors reviewed the full text of the selected documents carefully, and only the articles corresponding to the scope of this study (i.e., HRM research trends with the macro focus) were included. The result of the above procedure of the literature search reveals that 32 studies on HRM research trends in the global context, consisting of 23 narrative reviews and nine structural reviews, have been conducted, while 16 studies on HRM research trends in the Korean context, consisting of five narrative reviews and 11 structural reviews, have been conducted.

According to the taxonomy of Reference [9], the previous studies of HRM research trends in the global context consist of narrative and structural reviews at both the macro- and micro-level. Regarding the level of topic coverage, HRM research synthesis studies are divided into two categories: Macro focus (field level) analysis or microfocus (HRM subfields) analysis. At the macro field level, the scope of this study, the literature review reveals that the majority of the previous studies of HRM research trends were narrative reviews, but structural reviews have increased in recent years.

\subsection{The Studies on HRM Research Trends in the Global Context}

At the macro-focus field level, many scholars have conducted research trend studies on HRM with a narrative review (23 out of 32). Narrative reviews are often intuitive and provide significant insights by reviewing and integrating literature of HR and related fields rather than by using numerical analysis of research trends. Structural reviews of HRM research trends aim to show the exact status of the field and provide detailed information of the field research (9 out of 32), while narrative reviews focus on the overall outlining of the fields by structured literature review and offering insights.

Among structural reviews, some studies used bibliometric methods to analyze HRM research trends more systematically (4 out of 9). For example, Reference [9] asserted that previous studies of HRM research trends often intuitively organized HRM literature, whereas bibliometric methods provide systematic approaches to sort and review a large amount of literature. Additionally, they criticized recent bibliometric reviews of HRM research trends pointing out that the studies did not exhibit the advantage of bibliometric methods, since those studies reviewed only a fraction of the field by limiting the data sources to a specific journal. They conducted a co-words network analysis instead of a co-citation network analysis. Based on the bibliometric analysis of 12,157 HR articles published between 1992 and 2015 from the 140 journals, they categorized HRM studies into five topic areas: strategic HRM, experiencing HRM, employment relations, international HRM, and assessing people. Table 1 below shows detailed information about the most recent prior reviews of HRM research trends in the global context, including Reference [9]. 
Table 1. The most recent prior reviews of human resource management (HRM) research trends.

\begin{tabular}{|c|c|c|c|c|c|c|c|c|}
\hline No. & Review & $\begin{array}{c}\text { Key Topics Discussed and } \\
\text { Reviewed }\end{array}$ & Type of Literature & Period Covered & $\begin{array}{c}\text { Number of } \\
\text { Literature }\end{array}$ & Publication Title & Method & Limitation \\
\hline \multicolumn{9}{|c|}{ Narrative Reviews } \\
\hline 1 & [16] & $\begin{array}{l}\text { Historical development of the } \\
\text { American HRM field from the } \\
\text { late 19th century to the 21st } \\
\text { century }\end{array}$ & $\begin{array}{l}\text { Journals and books (on the } \\
\text { American HRM field) }\end{array}$ & $\begin{array}{l}\text { The entire period (from } \\
\text { the late 19th century) }\end{array}$ & Not specific & $\begin{array}{l}\text { Human Resource } \\
\text { Management Review }\end{array}$ & $\begin{array}{l}\text { Unstructured Literature } \\
\text { Review }\end{array}$ & Not Structural \\
\hline 2 & [17] & $\begin{array}{l}\text { Field's historical evolution } \\
\text { from a multiple stakeholder } \\
\text { perspective }\end{array}$ & $\begin{array}{l}\text { Not specific (all) (on the } \\
\text { relationship between HRM and } \\
\text { organizational effectiveness) }\end{array}$ & $\begin{array}{l}\text { The past three decades } \\
\text { (until 2014) }\end{array}$ & Not specific & $\begin{array}{l}\text { Journal of Organizational } \\
\text { Effectiveness: People and } \\
\text { Performance }\end{array}$ & $\begin{array}{l}\text { Unstructured Literature } \\
\text { Review }\end{array}$ & Not Structural \\
\hline 3 & [18] & $\begin{array}{l}\text { The HRM Field from the } \\
\text { Multi-stakeholder Perspective }\end{array}$ & Not specific (all) & 1984-2014 & Not specific & $\begin{array}{c}\text { Human Resource } \\
\text { Management }\end{array}$ & $\begin{array}{c}\text { Unstructured Literature } \\
\text { Review }\end{array}$ & Not Structural \\
\hline 4 & [19] & $\begin{array}{l}\text { Human Resource (HR) past, } \\
\text { present, and future }\end{array}$ & Not specific (all) & The entire period & Not specific & $\begin{array}{l}\text { Human Resource } \\
\text { Management Review }\end{array}$ & $\begin{array}{c}\text { Unstructured Literature } \\
\text { Review }\end{array}$ & Not Structural \\
\hline 5 & [20] & The future of HRM & Not specific (all) & The entire period & Not specific & $\begin{array}{c}\text { Human Resource } \\
\text { Management Review }\end{array}$ & $\begin{array}{c}\text { Unstructured Literature } \\
\text { Review }\end{array}$ & Not Structural \\
\hline \multicolumn{9}{|c|}{ Structural Reviews } \\
\hline 6 & [21] & $\begin{array}{c}\text { The research-practice gap in } \\
\text { HR }\end{array}$ & $\begin{array}{l}\text { Four HR-focused journals (two } \\
\text { academic and two } \\
\text { practice-oriented journals) }\end{array}$ & 1976-2005 & 6363 & $\begin{array}{l}\text { Human Resource } \\
\text { Management Review }\end{array}$ & $\begin{array}{l}\text { Structured Literature } \\
\text { Review }\end{array}$ & Not Bibliometric \\
\hline 7 & [22] & $\begin{array}{l}\text { Intellectual Structure of } \\
\text { Human Resources } \\
\text { Management Research }\end{array}$ & Human Resource Management & 1985-2005 & 551 & $\begin{array}{l}\text { Journal of the American } \\
\text { Society for Information } \\
\text { Science and Technology }\end{array}$ & Bibliometric Method & $\begin{array}{l}\text { Analyzing HRM articles in a } \\
\text { single journal }\end{array}$ \\
\hline 8 & [23] & $\begin{array}{l}\text { The Collective assessment of } \\
\text { the HRM field }\end{array}$ & $\begin{array}{l}\text { Journals (Meta-analysis articles } \\
\text { in the HRM field) }\end{array}$ & 40 years (until 2015) & 186 & $\begin{array}{l}\text { Human Resource } \\
\text { Management Review }\end{array}$ & $\begin{array}{l}\text { Structured Literature } \\
\text { Review }\end{array}$ & $\begin{array}{l}\text { Analyzing HRM articles that } \\
\text { employed a single method and } \\
\text { not bibliometric }\end{array}$ \\
\hline 9 & [8] & $\begin{array}{l}\text { Intellectual structure of human } \\
\text { resource management research }\end{array}$ & $\begin{array}{l}\text { The International Journal of } \\
\text { Human Resource Management }\end{array}$ & 2000-2012 & 1463 & $\begin{array}{l}\text { The International Journal } \\
\text { of Human Resource } \\
\text { Management }\end{array}$ & Bibliometric Method & $\begin{array}{l}\text { Analyzing HRM articles in a } \\
\text { single journal }\end{array}$ \\
\hline 10 & [9] & $\begin{array}{l}\text { Mapping the HRM field and } \\
\text { charting future directions }\end{array}$ & 140 journals in the HRM field & 1992-2015 & 12,157 & $\begin{array}{c}\text { Human Resource } \\
\text { Management Review }\end{array}$ & Bibliometric Method & $\begin{array}{l}\text { Using co-word network } \\
\text { analysis without } \\
\text { author-suggested keywords }\end{array}$ \\
\hline 11 & [24] & $\begin{array}{c}\text { Intellectual structure of HR in } \\
\text { the tourism and hospitality } \\
\text { management }\end{array}$ & $\begin{array}{l}\text { Four SSCI academic journals in } \\
\text { the realm of tourism and } \\
\text { hospitality management }\end{array}$ & 1997-2016 & 108 & $\begin{array}{c}\text { International Journal of } \\
\text { Contemporary } \\
\text { Hospitality Management }\end{array}$ & Bibliometric Method & $\begin{array}{l}\text { Analyzing HRM articles in a } \\
\text { single industry }\end{array}$ \\
\hline
\end{tabular}

Note. Not specific (all): Includes conference, magazine, web materials, etc. 
Topic clusters categorized by previous representative studies on HRM research trends can be summarized as follows. Among prior reviews described in Table 1, three structural reviews of HRM research trends using bibliometric methods were selected to compare the categorization of topic clusters. Other two structural reviews of HRM research trends $[23,24]$ were not included because they have critical limitations, as shown in Table 1. First, Reference [9] suggested five topic clusters based on bibliometric data, which are (a) strategic HRM, (b) experiencing HRM, (c) employment relations, (d) international HRM, and $€$ assessing people. Second, Reference [8] presented ten topic clusters based on bibliometric data using the descriptive explanation rather than labeling the name of each cluster. Third, Reference [22] proposed five clusters using factor analysis based on bibliometric data: (a) HR and performance, (b) culture and motivation, (c) international management of HR, (d) strategy structure and environment, and (e) strategic management of HR. Notably, topic clusters of (a) strategic HRM and performance, and (b) international HRM labeled by the authors of this study were relatively similar to the common subjects in the classification of the previous studies on HRM research trends (see Table 2). However, finding another direct link among other clusters seems to be difficult because these three studies presented different clusters in different ways. Table 2 above presents and compares the detailed information about topic clusters categorized by these studies.

Although previous studies on HRM research trends in the global context provided very useful information about the structures of HRM research trends, they have several critical limitations. The critical limitations of these previous studies can be discussed in the three aspects: (a) The method of analysis, (b) the data of analysis, and (c) the results (i.e., topic clusters) of analysis.

First, regarding the method, the prior reviews of HRM research trends in the global context have shown a tendency to derive research results through a less sophisticated review type of analysis (i.e., narrative reviews base on the unstructured literature review method) than the structural reviews. Among structural reviews, some studies used to analyze HRM research trends more systematically using bibliometric methods (4 out of 9), while other studies are based on the structured literature review method. Although a few bibliometric methods have been used for HRM research trend studies in the global context, no keyword network analysis method has been used. In short, the prior bibliometric structural reviews focused on analytical methods, such as co-citation network analysis (e.g., References $[8,22,24])$, to explore "structural", not "semantic" aspects of HRM research trends because there is a limitation in that no structural review uses the keyword network analysis method.

Second, regarding the data, some studies are limited by analyzing HRM articles in a single journal (e.g., References [8,22]), analyzing HRM articles in a single industry (e.g., Reference [24]), or analyzing HRM articles that employed a single method (e.g., Reference [23]). Although these studies contributed to the field of HRM by revealing an important part of the knowledge structure of HRM research trends, the limitations could lead to a biased result of the analysis.

Third, regarding the results, previous studies are also limited in that the procedure and criteria by which they categorized the topic clusters have less accurate aspects. For instance, narrative reviews using unstructured literature review methods usually depended on an intuitive categorization of HRM research trends, while structural reviews using structured literature review methods also have similar limitations. As mentioned before, prior structural reviews using the bibliometric methods (e.g., co-citation network analysis) also have the limitation that the procedure and criteria of the topic clusters were derived from "structural", not "semantic" aspects of HRM research trends. The limitation of prior structural reviews using the bibliometric methods results in the problem that there is no standardized procedure or criteria on which the future studies can depend. The lack of "semantic" aspects of HRM research trends also leads to difficulties in analyzing the results at the thematic cluster level. 
Table 2. Comparisons of topic clusters among three bibliometric reviews of HRM research trends.

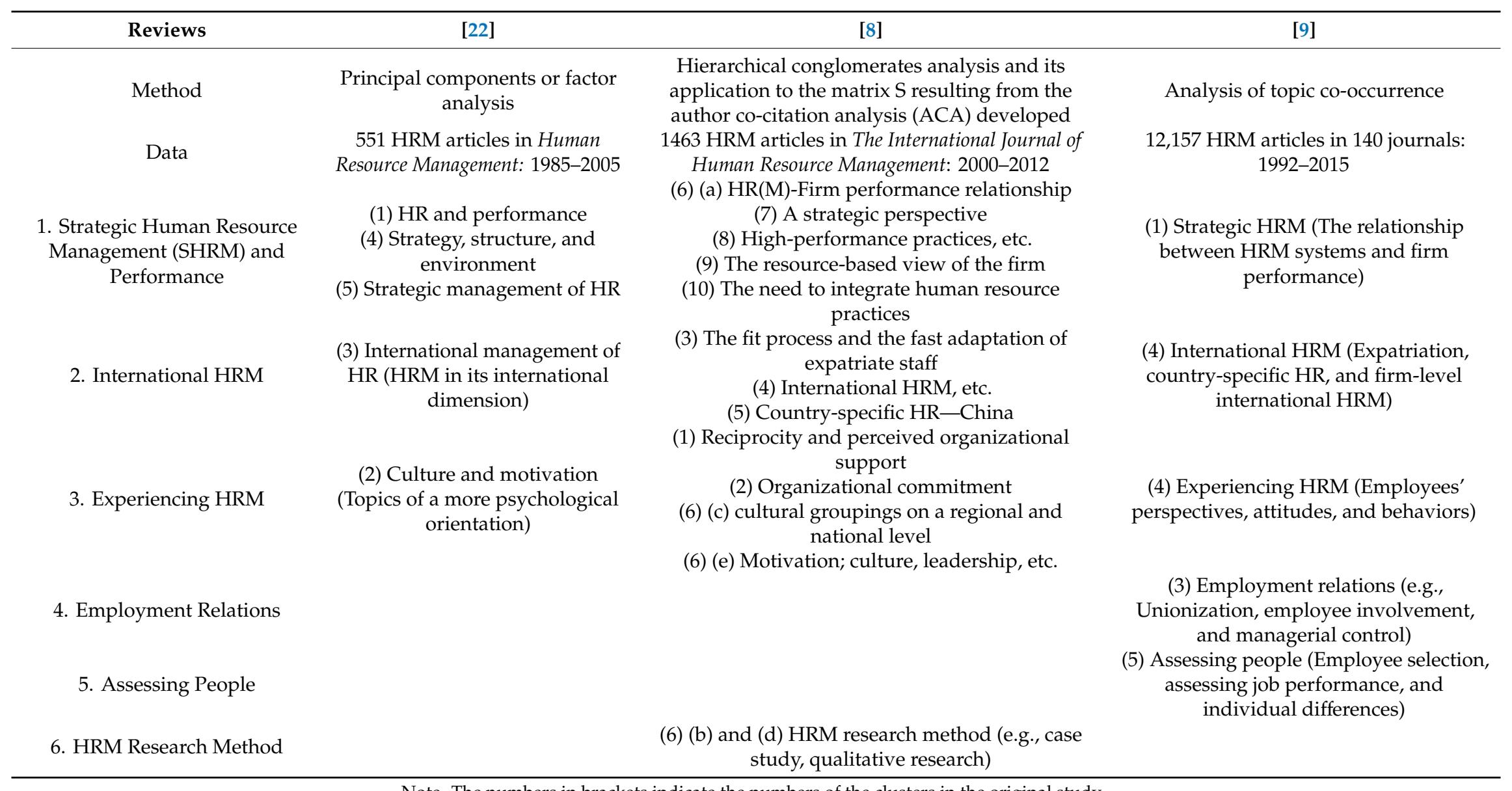

Note. The numbers in brackets indicate the numbers of the clusters in the original study. 
Furthermore, the above-mentioned limitation of previous studies in the global context regarding the categorization of the topic clusters also has a critical link to the missing data from local HRM research trends all over the world. As previous studies on HRM research trends in the global context explored and identified major topic clusters by only analyzing the literature written in English, their results could be biased regarding the language, due to data that is not inclusive. As the previous studies using the bibliometric methods have a topic cluster labeled as international HRM in common (see Table 2), the need to include missing data from local HRM research trends cannot be underestimated. Considering that [8], which analyzed HRM articles in a single journal focusing on the international HRM context, identified the cluster regarding country-specific HR (i.e., China) in addition to the cluster regarding international HRM, it is very likely that the exclusion of the literature from local HRM research trends could lead to the biased result of the research trend studies in the global context.

Thus, it is possible that previous studies in the global context failed to provide comprehensive results, due to the missing data in two ways. One notable thing is that they were not able to describe the complete picture of the entire global HRM research trends because the missing data from local HRM research trends all over the world could have influenced the results (i.e., topic clusters). Another possible missing point is that they could not identify the accurate information about the topic cluster labeled as international HRM in Table 2, and consequently, failed to provide the foundation of the comparative study among different regions and/or countries (e.g., Western HRM vs. Asian HRM).

In short, the inclusion of the literature from local HRM research trends could contribute to both (a) the entire global HRM research trends and (b) the topic cluster labeled as international HRM, and consequently, would add a great value to the future studies on HRM research trends in the global context. For instance, analyzing the HRM research trends in Korea in the Asian region regarding the "country-specific HR" ([9], p. 382) could be a great starting point to investigate better the cluster regarding international HRM presented by the prior reviews and to compare HRM research trends among various regions and/or countries.

\subsection{The Studies on HRM Research Trends in Korea Context}

Korea has often been cited as a success story of the "miracle of the Han River," which has increased in a short period $[25,26]$. Korea has overcome the devastated by World War II and the Korean War and became the twelfth largest economy based on the GDP and the seventeenth-largest trading partner in the world. According to the World Bank, Korea is the second-highest country of the Human Capital Index (Productivity relative to the benchmark of complete education and full health) among 157 countries in the world as 0.84 , followed by Singapore(0.88) [27]. While much has been written about the economic foundations of such growth, and some have been written about Korean HRM practices [28-31], very little is known about HRM research trend.

In 2013, the International Journal of Human Resource Management published a special issue that analyzed the role of HRM in Korea's globalization efforts and experience. In the introduction part of the special issue, Reference [32] divided four phases of Korean HRM system change, explained the antecedents and consequences of HRM transition, and prospected the issue facing Korean HRM in the future. As shown in Table 3 below, they explained that the Korean HRM system has evolved into seniority-based paternalistic HRM before 1987, competency-enhancing HRM in 1987-1997, and performance-based HRM in 1997-2007. They pointed out that the post-2007 of Korean HRM is facing the "top talent"-focused and flexibility-oriented HRM paradigm. In the last decade, the diversity issues caused by globalization and the rise of multinational corporations (MNCs) have affected the overall HRM feature. In particular, as the competitive strategy of Korean MNCs has shifted from cost-saving to producing highly standardized products and marketing approaches, and interest in knowledge management has increased, HRM systems have been rebuilt to support this, especially in the MNCs. 
Table 3. Chronology of Korean HRM Practice change.

\begin{tabular}{|c|c|c|c|c|c|}
\hline \multicolumn{2}{|c|}{ Category } & pre 1987 & 1987-1997 & 1997-2007 & post 2007 \\
\hline \multicolumn{2}{|c|}{ HRM system } & $\begin{array}{l}\text { Seniority-based } \\
\text { paternalistic }\end{array}$ & Competence-enhancing & Performance-based & $\begin{array}{l}\text { Performance-based and } \\
\text { Flexibility-oriented }\end{array}$ \\
\hline \multirow{4}{*}{$\begin{array}{l}\text { Features of } \\
\text { HRM }\end{array}$} & Staffing & Internal & Internal & Internal and external & Multi-national \\
\hline & Security & Strong & Strong & Weak and strong & Weak and strong \\
\hline & Training & Extensive & Extensive & $\begin{array}{l}\text { Duality (extensive } \\
\text { for top talent) }\end{array}$ & Extensive for Top talent \\
\hline & Reward & Seniority-based & $\begin{array}{c}\text { Seniority and competence } \\
\text { based }\end{array}$ & Performance-based & Performance-based \\
\hline
\end{tabular}

Source: Revised by author based on Reference [32], p. 116.

Besides, Reference [33] analyzed changes in Korean HRM practices due to globalization, and [29] introduced HRM practices, such as Samsung's HRM system and recent changes. Reference [28] also conducted a comparative study of HRM trends in Korea and Taiwan. There were numerous discussions from the various angles about the history, background, and the specific practices of Korean HRM, but how the HRM research was scaffolded was not introduced in the international journal. The reasons why Korean research trends should be discussed are as follows. First, although there is mountainous empirical research on the specific topics (woods) of HRM in the Korean context in various international journals, we have insufficient understanding about Korean HRM research trend (forests) in general, and now, this is the time to move the lens from the wood to the forest. Second, Korea has a unique context of the HRM practice development that has simultaneously evolved from the influence of traditional Confucian culture and the active benchmarking of Western HRM practices. HRM practice and HRM research are closely linked; therefore, it is meaningful to see how the context of Korean HRM is reflected in research. This work will enable an in-depth understanding of HRM research in the Korean context and contribute to the development of comparative studies in various cultures.

Meanwhile, in the Korean Journal, Korean scholars published a number of studies to analyze HRM trends as shown in Table 4 below $[4,10,34,35]$. Some research trend studies in Korean HRM tend to use structured literature review approach. Reference [4] employed the macro-focus approach to explore the entire HRM area. This study is noteworthy because it analyzed all domains' entire HRM sector, while other previous studies on Korean research developments concentrated on the HRM field's limited domain. Reference [4] reviewed 696 papers published between 1991 and 2007, which consisted of 218 papers in the Korean Journal of Management and 478 papers in the Proceedings of the Korean Academy of Management. Reference [4]'s study divided the Korean HRM research field into six areas: organizational behavior, organizational theory, personnel management, industrial relations, strategic management, and research methodology. Such research domains are categorized based on the subdivisions of the Korean Academy of Management, and it is significant because the Korean HRM research patterns are closely examined and linked into specific subfields. Nonetheless, Reference [4] has a limitation because the studies analyzed in this study are categorized by the subjective judgment of the researcher, not by objective quantitative evidence.

Other macro-focus approaches to HRM research trend studies also analyzed one or two specific domains of HRM in Korea. Reference [34] analyzed research trends in organizational behavior and organizational theory by analyzing research articles published from 1979 to 2008 in The Korean Journal of Human Resource Management. According to this study, organizational behavior has been increasing steadily since the 1980 s, and reaches to approximately $70 \%$ of entire publication in the journal; however, research on organizational theory has decreased to $18.2 \%$ in the $2000 \mathrm{~s}$ from $34.4 \%$ in the 1980s. They reported that the most frequently studied subjects in the organizational behavior domain were organizational attitudes $(26.6 \%)$, followed by leadership $(16.3 \%)$. Additionally, in the organization theory area, organizational learning $(27.8 \%)$ was the most prevalent topic, followed by organizational culture (26.6\%). Reference [10] investigate the research trend in organizational theory and research trends by analyzing journal articles from three HRM-related journals in Korea. The focus of this research was the use of theory in organization and strategic management research, and this study criticizes the fact that existing Korean HRM literatures tend not to develop original theories, concepts, 
variables, or perspectives to explain the unique characteristics of Korean management, but tend to borrow theories developed in Western to Korean data. Reference [35] analyzed 315 research articles on labor relations from six Korean journals. They found that $37 \%$ of the articles were about outcome and change of labor relation, including research topics of workplace innovation and skill, labor flexibility, and institutional pressure. The second dominant topics were a relational aspect of labor relation $(26 \%)$, such as collective bargaining, labor conflict, and negotiation and adjustment.

Table 4. Review of Korean HRM Research Trends.

\begin{tabular}{|c|c|c|c|c|}
\hline Review & [4] & [34] & [10] & [35] \\
\hline $\begin{array}{l}\text { Key Topics } \\
\text { Discussed }\end{array}$ & The Entire Filed of HRM & $\begin{array}{c}\text { OB (Organizational } \\
\text { Behavior) and OT } \\
\text { (Organization Theory) }\end{array}$ & $\begin{array}{l}\text { OT (Organization Theory) } \\
\text { and Strategic management } \\
\text { (SM) }\end{array}$ & Industrial Relations (IR) \\
\hline $\begin{array}{l}\text { Reviewed Type of } \\
\text { Literature }\end{array}$ & $\begin{array}{c}\text { Korean Journal of } \\
\text { Management; The } \\
\text { Proceedings of Korean } \\
\text { Academy of Management } \\
\text { Conference }\end{array}$ & $\begin{array}{c}\text { The Korean Journal of } \\
\text { Human Resource } \\
\text { Management }\end{array}$ & $\begin{array}{c}3 \text { Academic journals in } \\
\text { Management }\end{array}$ & $\begin{array}{l}6 \text { Academic journals in } \\
\text { Management }\end{array}$ \\
\hline Period Covered & $1991-2007$ & 1979-2008 & 1980-2013 & 1994-2014 \\
\hline $\begin{array}{l}\text { Number of } \\
\text { Literature }\end{array}$ & 696 & 337 & 435 & 315 \\
\hline Method & $\begin{array}{c}\text { Structured Literature } \\
\text { Review }\end{array}$ & $\begin{array}{c}\text { Structured Literature } \\
\text { Review }\end{array}$ & $\begin{array}{c}\text { Structured Literature } \\
\text { Review }\end{array}$ & $\begin{array}{c}\text { Structured Literature } \\
\text { Review } \\
\text {-Explained that Korea }\end{array}$ \\
\hline Key Results & $\begin{array}{l}\text {-Analyzed research rates } \\
\text { into six categories } \\
\text {-Korea's HRM research was } \\
\text { initially centered on research } \\
\text { of organizational behavior, } \\
\text { but later diversified into } \\
\text { various topics. } \\
\text {-Increased in the proportion } \\
\text { of literature related to } \\
\text { industrial relations since the } \\
\text { late 1990s }\end{array}$ & $\begin{array}{l}\text {-Criticized of the bias in } \\
\text { the field of organizational } \\
\text { behavior } \\
\text {-Increased interest in new } \\
\text { research topics (social } \\
\text { capital, social networks) } \\
\text { since the late 2000s } \\
\text {-Criticized the gradual } \\
\text { increase of empirical } \\
\text { research (vs. theoretical) }\end{array}$ & $\begin{array}{l}\text {-Examined the theories in } \\
\text { the previous study focused } \\
\text { on organization theory } \\
\text { and strategic management } \\
\text {-Theory was utilized more } \\
\text { problem-centered (vs. } \\
\text { paradigm-centered) } \\
\text {-Research were biased } \\
\text { toward quantitative } \\
\text { methodologies (vs. } \\
\text { qualitative ones) }\end{array}$ & $\begin{array}{l}\text { research focused on the } \\
\text { practical IR issues } \\
\text {-Significant increase in } \\
\text { research using secondary } \\
\text { data } \\
\text {-Large proportion of research } \\
\text { using empirical research and } \\
\text { cross-sectional data } \\
\text {-Growing number of studies } \\
\text { conducted industrial- and } \\
\text { national-level (vs. } \\
\text { individual- and } \\
\text { workplace-level) }\end{array}$ \\
\hline Limitation & $\begin{array}{l}\text {-Classified literature } \\
\text { subjectively }\end{array}$ & $\begin{array}{c}\text {-Classified literature } \\
\text { subjectively } \\
\text {-Limited to specific HRM } \\
\text { Field (OB/OT) }\end{array}$ & $\begin{array}{c}\text {-Classified literature } \\
\text { subjectively } \\
\text {-Focused on the utilizing of } \\
\text { organization theory } \\
\text {-Limited to specific HRM } \\
\text { Field (OT/SM) }\end{array}$ & $\begin{array}{c}\text {-Classified literature } \\
\text { subjectively } \\
\text {-Limited to specific HRM } \\
\text { Field (IR) }\end{array}$ \\
\hline
\end{tabular}

The results of analyzing the research trends of the Korean HRM literature in the Korean Journal show that Korean HRM research has a high interest in organizational behavior and tends to have a high weight of empirical studies based on the quantitative approach. Additionally, in the late 1990s, the financial crisis, which Korean people called 'International Monetary Fund (IMF) crisis', expanded interest in industrial relations, and since the late 2000s, approaches using more diverse themes and methods have been attempted.

Although the Korean Journal and researcher attempted to summarize the trends of HRM research from various perspectives, some limitations are noted. First, they took the structural perspective, but the researcher subjectively determined the criteria for classifying and organizing previous literature. Second, there is a limitation that the thematic development of Korean HRM research has not been analyzed more systematically, focusing on the ratio of the literature for each category they classified and how these ratios increase and decrease. As mentioned in the review of the global context, more systematic, semantic, and reproducible studies are needed to analyze HRM trends in Korean research.

Budhwar et al. [36] stressed the need for developing unique and independent management models in Asian countries for the HR function to play a more strategic role. Since the HR research have an intimate connection with HR practice indispensably, this discussion can be extended to HRM research. In particular, Korean researchers [4,34] criticize the fact that Korea's HRM research does not provide its own theory and has a limitation regarding verifying the results of western context iteratively into the Korean context. Thus, it is necessary to explore verifying what the difference and similarity is between the trends of Korean HRM research and HRM trends in the global context, and how this can 
be interpreted. This study will contribute to providing a ground for a deeper understanding of the result from each HRM studies conducted in the Korean context.

\section{Method}

The purpose of the study and the research questions determined the search criteria and selection of database. The purpose of this study is to examine the research trend of HRM in Korea through the relationship between the author's provided keywords. To meet the research objectives, we selected the Korean Citation Index (KCI) database that is a certified academic database in Korea. The KCI index is the only certified academic citation index database that "is the system to analyze citation relationship among articles based on the database constructed by information about domestic journals, articles and reference" [37]. In the KCI (https://www.kci.go.kr/kciportal/main.kci?locale=en) citation database, we collect research articles using HRM specific journals in Korea. As our searching strategy is systematically searching for all the articles in representative HRM journals, three top HRM-focused journals (i.e., Journal of Organization and Management, Korean Journal of Management, and Journal of Human Resource Management Research) were identified. Figure 1 shows the whole process of analysis procedures, including data collection, keywords coding, and analysis phase.

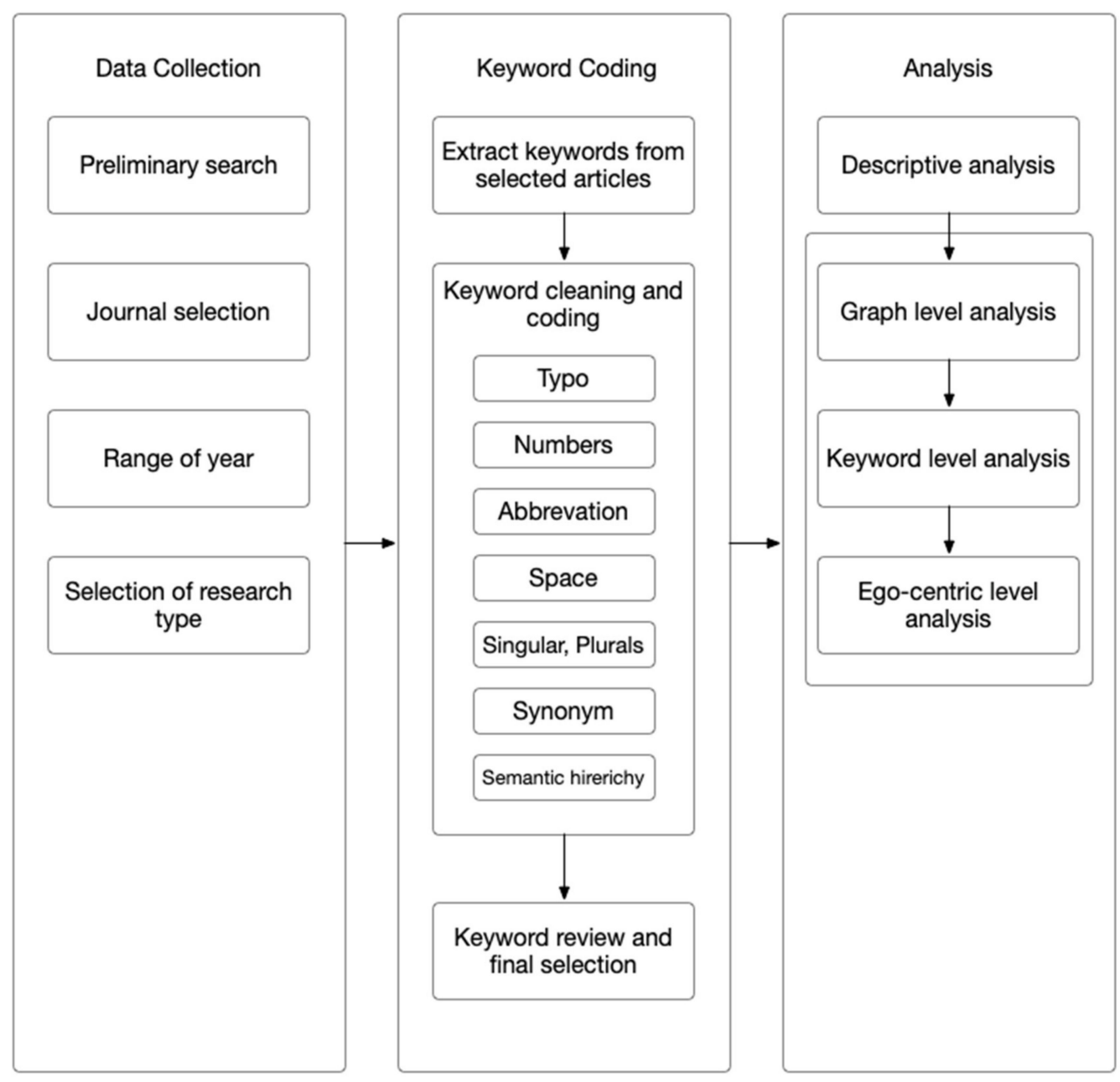

Figure 1. Data collection and analysis procedure.

\subsection{Unit of Analysis}

In this study, a unit of analysis is author suggested keywords. In bibliometrics studies, diverse sources often used for revealing semantic structure, such as title, revised keywords from a database, the author suggested keywords, and abstract or some study use whole text. In a case that extracts 
keywords from title or abstract, the keywords often reveal word level of sentiment. Although this approach was used in early bibliometric studies, it has now been replaced in the area of natural language processing.

Moreover, it often reveals word-level sentiment rather than a topical structure, and the quality of the analysis is more sensitive by the cleaning process than the author suggested keywords and database-specific keywords. The author suggested keywords are the meta-data of articles that specifically selected keywords by authors for representing the topical sentiment of the article. On the other hand, some studies choose keywords from meta-data, such as author keywords or revised keyword from the database. In the usual case, revised keywords from the citation database would be beneficial regarding data cleaning (e.g., web of science). However, not all citation databases have revised keyword from the citation index. The KCI database, which is selected for this study, does not have a revised keyword. There are two columns for keywords in the KCI database, keywords (Korean) and keywords in English. In using the author suggested keyword for the analysis, the issue is that keywords are not normalized or are mistyped. To solve this problem, we devised a keyword cleaning and coding procedure for this study (see Figure 1 and the keyword coding section)

\subsection{Data Collection}

A total of 1158 research papers published by three peer-reviewed HRM journals in Korea that were published from 2007 to 2018 were collected. The selected journals are Korean Journal of Management (248 research articles), Journal of Human Resource Management Research (605 research articles), and Journal of Organization and Management (305 research articles). These three journals have a high authority and influence while focusing on the overall HRM field in business administration among Korean journals. Specifically, according to the data of the 2018 KCI Impact Factor, Journal of Organization and Management, Korean Journal of Management, and Journal of Human Resource Management Research ranked second, third, and sixth, respectively, among 83 academic journals in business administration. As the inclusion criteria, both empirical and non-empirical research articles, such as review articles and conceptual studies were selected. By the exclusion criteria, non-research articles, such as editorials, front- and end- matter, book chapters, book reviews, and conference papers were excluded.

As articles on Korean HRM in international journals written in English have not been included, this study limits the range of samples to three major HRM journals in Korea. However, we decided to focus on publications in Korean journals written in Korean, due to the following two reasons. First, the primary focus of this study is to fill the research gap in previous studies on HRM research trends in the global context, whose results could be biased by analyzing the literature written in English. Second, it would not be technically appropriate to apply the same keyword cleaning and coding procedure if we depended on another academic database (e.g., Web of Science, Scopus, etc.) to include international journals written in English, which is quite different from the KCI database.

\subsection{Keyword Coding}

Keywords are converted to a lowercase form in the extraction step, but capitalization is maintained for abbreviations. Plural forms are changed to singular. Symbolic characters are removed, changed, or left depending on coding criteria (see Table 5). Next, keywords screening to fix typos, abbreviations, and numeric characters were conducted. Then, keywords that include a proper noun, name of a person, name of a region, a statistical or methodological concept were identified and processed based on the coding criteria. Then, unnecessary white space was removed. During the keyword revision, sometimes, unexpected white space between words occurred (e.g., organization development and organization development). By removing unnecessary white space between a pair of words that includes the same words but in a different form by space, it identified the pair of words as same the keywords. This procedure was executed by four researchers in this study multiple times. 
Table 5. Keyword coding criteria.

\begin{tabular}{|c|c|c|c|c|c|}
\hline Category & Details & Purpose & Decision & Standard & Example \\
\hline Author keywords & $\begin{array}{l}\text { Author suggested } \\
\text { keywords }\end{array}$ & To select a proper keyword for analysis & Leave & $\begin{array}{l}\text { A keyword that contain a unique } \\
\text { meaning }\end{array}$ & \\
\hline Research purpose & Research method & To clarify relations between keywords & Delete & $\begin{array}{l}\text { A keyword that represent a research } \\
\text { method alone }\end{array}$ & $\begin{array}{l}\text { Structural equating modeling (SEM), } \\
\text { Hierarchical linear modeling (HLM), } \\
\text { Social network analysis (SNA) }\end{array}$ \\
\hline Research purpose & Name of region & To clarify relations between keywords & Delete or leave & $\begin{array}{l}\text { Whether it used alone or construct a } \\
\text { meaning in a context }\end{array}$ & Korea, China \\
\hline Research purpose & A proper noun & To clarify relations between keywords & Delete or leave & $\begin{array}{l}\text { Whether it used alone or construct a } \\
\text { meaning in a context }\end{array}$ & Jaebeul \\
\hline Туро & $\begin{array}{l}\text { Symbols (Hyphen, } \\
\text { quotation mark) }\end{array}$ & $\begin{array}{l}\text { To prevent over- or under-estimation of } \\
\text { link between keywords }\end{array}$ & Revision & $\begin{array}{l}\text { Delete quotation mark. For other } \\
\text { grammatical symbol has used properly } \\
\text { in standard English }\end{array}$ & $\begin{array}{l}\text { resource-based view, resource-based } \\
\text { view }\end{array}$ \\
\hline Tyро & Typo & $\begin{array}{l}\text { To prevent over- or under-estimation of } \\
\text { link between keywords }\end{array}$ & Revision & Obvious typo & \\
\hline Туро & Space & $\begin{array}{l}\text { To prevent over- or under-estimation of } \\
\text { link between keywords }\end{array}$ & Revision & Unnecessary usage of space & \\
\hline Normalization & Capital/small letters & $\begin{array}{l}\text { To prevent over- or under-estimation of } \\
\text { link between keywords }\end{array}$ & Revision & Revise to small letter & Resource Based View \\
\hline Normalization & Abbreviation & $\begin{array}{l}\text { To prevent over- or under-estimation of } \\
\text { link between keywords }\end{array}$ & Revision & Keep in consistence in dataset & POS, Perceived Organizational Support \\
\hline Normalization & Singular/plural & $\begin{array}{l}\text { To prevent over- or under-estimation of } \\
\text { link between keywords }\end{array}$ & Revision & Singular & Employees engagement \\
\hline Normalization & Numbers & $\begin{array}{l}\text { To prevent over- or under-estimation of } \\
\text { link between keywords }\end{array}$ & Revision & $\begin{array}{l}\text { Whether it used alone or construct a } \\
\text { meaning in a context }\end{array}$ & 360-feedback \\
\hline Normalization & $\begin{array}{l}\text { U.S English/British } \\
\text { English }\end{array}$ & $\begin{array}{l}\text { To prevent over- or under-estimation of } \\
\text { link between keywords }\end{array}$ & Revision & Revise to U.S English standard & Organization/organization \\
\hline Normalization & Integration of form & $\begin{array}{l}\text { To prevent over- or under-estimation of } \\
\text { link between keywords }\end{array}$ & Revision & Convert to noun form & \\
\hline Separation & Word separation & $\begin{array}{l}\text { To prevent over- or under-estimation of } \\
\text { link between keywords }\end{array}$ & Revision & Keywords that combined by 'and', 'or' & $\mathrm{OCB}$ and Training \\
\hline Similar concepts & Dependency in meaning & $\begin{array}{l}\text { To prevent over- or under-estimation of } \\
\text { link between keywords }\end{array}$ & Revision & $\begin{array}{l}\text { Based on judgement that the keywords } \\
\text { construct unique meaning }\end{array}$ & $\begin{array}{l}\text { Organizational development, } \\
\text { organization development }\end{array}$ \\
\hline Similar concepts & Hierarchy in meaning & $\begin{array}{l}\text { To prevent over- or under-estimation of } \\
\text { link between keywords }\end{array}$ & Revision & $\begin{array}{l}\text { Based on judgement that the keywords } \\
\text { construct unique meaning }\end{array}$ & \\
\hline Similar concepts & Synonym & $\begin{array}{l}\text { To prevent over- or under-estimation of } \\
\text { link between keywords }\end{array}$ & Revision & $\begin{array}{l}\text { Integrated to commonly used words or } \\
\text { terms }\end{array}$ & $\begin{array}{l}\text { evaluation, } \\
\text { appraisal }\end{array}$ \\
\hline
\end{tabular}


After the basic cleaning process, a coding procedure for keywords with similar meanings or hierarchical structure between keywords was executed. Unlike cleaning and coding of the apparent typos, this procedure includes a risk of researcher's bias in nature. To reduce bias on keyword coding, we used a keyword corpus from the previously published documents: The Human Resource Body of Knowledge (HRBok) [38] and HRM Map [9]. In this procedure, keywords were compared with the keyword list from these two sources and were revised, followed by keywords from the HRBok [38] and HRM Map (http://bit.ly/HR-Map) [9]. The remaining keywords following the keyword coding procedure were processed (i.e., delete, retain, or change) based on group discussion between researchers in this study. To ensure the quality of coding and agreement, we run multiple rounds of keyword coding and the rating process. After rating keywords, members discussed why they revised. After a few rounds (round 7), we felt it had reached a level of agreement and quality. The final Fleiss' Kappa [39] for $\mathrm{m}$ raters was 0.83

\subsection{Analysis}

In the keywords co-occurrence network, a pair of keywords that occurred together are considered to be connected. By cumulation of co-occurrences, a set of keywords forms a network structure that approximately represents a conceptual construction of a scientific field. Often normalization of the connection between keywords is considered in other studies [5]. Although it is a useful approach, the present study used to link (co-occurrence) count rather than normalized weighted value for centrality measure.

\subsubsection{Network Level Analysis}

The network-level analysis provides information about the whole structure of a network [40]. In this level, network level properties like network size, number of components, centralization of a network, density, clustering co-efficiency, and diameter were identified. Findings from this level represent a profile of semantic structure.

\subsubsection{Thematic Cluster-Level Analysis}

This level of analysis is often called sub-group analysis and community detection. The thematic procedure includes the normalization of the keyword links, mapping, and clustering. Network distributions are significantly different between nodes in the number of edges. This study applied "the association strength" normalization ([41], p. 531). For the keyword mapping, multi-dimensional scaling (MDS) was used. Keywords that are coordinated by the MDS locate closely with each other if they have a strong relation. Clustering gives information about what keywords are associated in a theme. Often, this approach uses distance measure between keywords. This study uses a smart local moving algorithm used for clustering keywords [42]. A common approach for the clustering in keyword network analysis is similarity-based clustering. A similarity matrix has been extracted from a co-occurrence matrix by normalization process. In the normalizing process, the co-occurrence matrix was corrected by applying the differences in the total number of occurrences of the keywords. Reference [41] showed that clustering based on association strength was the best solution for the normalized co-occurrence data by surveying and comparing the popular other clustering method. In this study, association strength [43] has been used for calculating the proximity index. The similarity of sij between two keyword I and $\mathrm{j}$ was calculated by the following equation. 


$$
S i j=C i j / W i W j
$$

In this equation, the similarity between a pair of keyword $S i j$ is expressed as a proportion of the number of co-occurrences of item $i$ and $j$ that is divided by the product of the total number of occurrences of item $i$ and $j[41]$.

\subsubsection{Keyword Level Analysis}

Keyword level analysis showed structural characteristics of a keyword that is based on a keyword's location and connection with other keywords. There are many indicators for this level. Especially, the centrality measure in social network analysis has developed continuously (see http: //schochastics.net/sna/periodic.html). Each centrality measure calculates the value of a node (a keyword in this case) in a different perspective. For example, while degree centrality indicates the degree of the popularity and visibility of a node, betweenness centrality indicates the degree of how a node provides connection between a pair of node by calculating percentage of shortest paths that pass through the node (keyword) [44]. In this study, frequency, degree centrality. As mentioned previously, many other centrality measures can be used for the importance of a node (a keyword); however, some centrality measures make it hard to interpret the result correctly. Keyword frequency indicates how many times a keyword has occurred. Degree centrality is the value from the counting links of a node has with other nodes. Often, text mining starts with counting words. As the basic descriptive information, keyword frequency was suggested. Degree centrality is often interpreted as a popularity or a visibility measure [44]. In this study, we choose the degree centrality measure because degree centrality has used widely in keyword network analysis and is clear enough in many contexts. Besides, there is no previous agreement about which centrality measure should be used. Degree centrality provides quite straightforward information about the importance of nodes in a network, popularity, and visibility.

\subsubsection{Ego-Centric Level Analysis}

Often, the semantics of a term can be clarified by the relation with other keywords and the structure that is constructed by alters. In general, the ego-centric network indicates a network that an individual (ego) possessed. Ego-centric network were extracted from whole network, and then the title keywords were removed. For example, in job performance's ego-centric network, keywords that have a direct connection with job performance were selected and extracted, and then job performance were deleted. In a keyword level of an ego-network, the top ten keywords based on degree centrality were suggested.

For the bibliometric and network analysis, multiple software was used. For the bibliometric analysis and network analysis, bibliometrics package in R 4.2 [45] and igraph [46] packages in $\mathrm{R}$ software were used, and for the visualization, Gephi 0.9 [47] and Vosviewer 1.2 [41] were used. The code for the analysis and data have been uploaded to open science foundation (OSF) storage (https:/osf.io/j7rz5/?view_only=0c2e25fa308d45a296675d01e406641a) to support reproducibility and reusability for other researchers. For the main analysis, such as keyword network and clustering analysis, Bibliometrics package in $\mathrm{R}$ was used. Bibliometrx is an open-source tool for quantitative research in scientometrics and bibliometrics [45]. Ego-centric keyword network has visualized using gephi. Gephi is an open-source network analysis and visualization tool. For the brief entire map of the keyword, VOSviewer was used. VOSviewer is also an open-source bibliometrics and scientometrics tool. 


\section{Findings}

\subsection{Descriptive Analysis}

A total of 2596 keywords from 1158 article were identified. Average and standard deviation of yearly publication indicates the productivity of the Korean HRM journals. In this study, the average publication rate of the HRM journal articles from 2007 to 2018 was 96.5 articles per year (standard deviation $=10.81$ ). The distribution of keywords was severally skewed in range two keywords per an article to twelve keywords per article. If we estimate the number of keywords, it would be a serious problem; however, our findings are based on the calculation of keyword structure based on graph theory that is formed by the co-occurrence of keywords.

The most frequent the top ten keywords are organizational commitment (138), job satisfaction (106), turnover (80), OCB (93), POS (42), transformational leadership (41), LMX (41), performance (35), innovative behavior (31), and job performance (29) (See Figure 2b). Keyword occurrence frequency by year showed a dynamics of keyword occurrence (See Figure 2a). For instance, organizational commitment showed the highest frequency in cumulative graph, but it has also decreased rapidly since 2015. Most keywords showed a wavelet pattern, but job performance showed a stead increased curve since 2017.

\subsection{Network Level Analysis}

Keyword network derived from 1158 articles consists of 2165 keywords and the number of links in the keywords network was 8385. The network diameter in the networks was ten. Average path length was 3.78 , indicating that nearly all keywords can be connected within four steps on average.

Density is a network level indicator that showed how densely the keywords have connected each other, and the clustering coefficient provides information about the probability of how nodes (keywords) are connected with other neighbor nodes (keywords). Thus, density showed a degree of connection in a global view, and the clustering coefficient indicates the degree of connection in local area. In this study, network density of the Korean HRM keyword network was 0.003 , and clustering coefficient was 0.16 , indicating that about $0.3 \%$ of connection were observed from all possible connections, and the possibility of a keywords has connection with other neighboring keywords is $16 \%$. It indicates that keywords networks in Korean HRM study have sparse connection in global area and a tighter connection in local area. Additionally, degree centralization indicator shows how a network is hierarchically structured. In this network, degree centralization indicator was 0.136 . With this information, we can picture the characteristics of the Korean HRM keyword network. The Korean HRM's semantics, which were revealed by author, suggested keywords showed as a knowledge construction that loosely connected local themes that consist of closely connected keywords in local cluster as theme, and the connection are hierarchically structured by a few dominant keywords.

\subsection{Thematic Cluster-Level Analysis}

Each cluster indicates a thematic representation. Cluster names are given based on keyword frequency in the cluster. Figure 3 shows summarized keywords network, and keyword color represents the association of clusters and the coordination of keywords assigned by calculation of distance measure. We found nine keyword clusters and labeled them based on keywords in each cluster as follows: strategic HRM, creativity and innovation, employee emotional issue, relationship and attachment, group dynamics, career issue, fairness and justice in organization, commitment and satisfaction, and organizational support (See Table 6). 


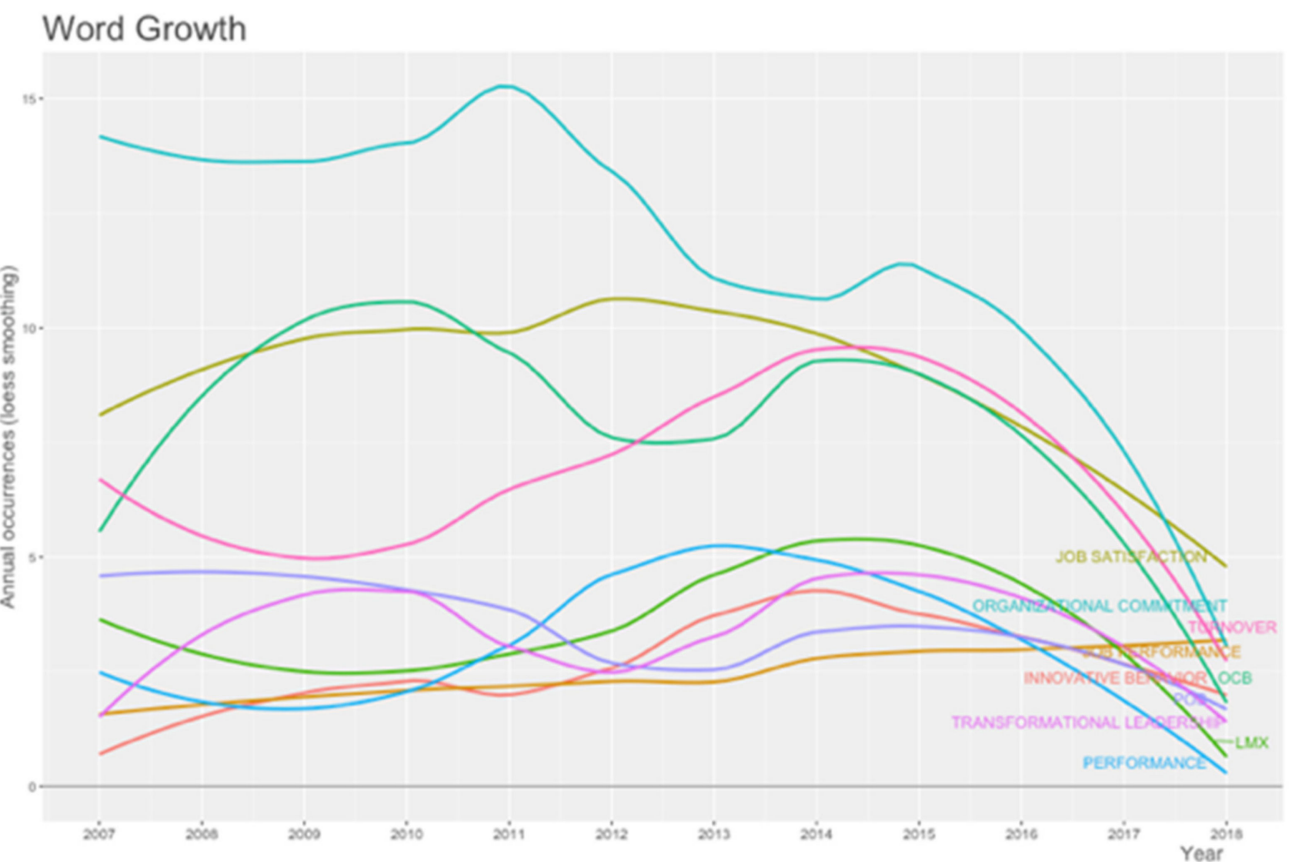

(a) word growth of top 10 keywords by single year based

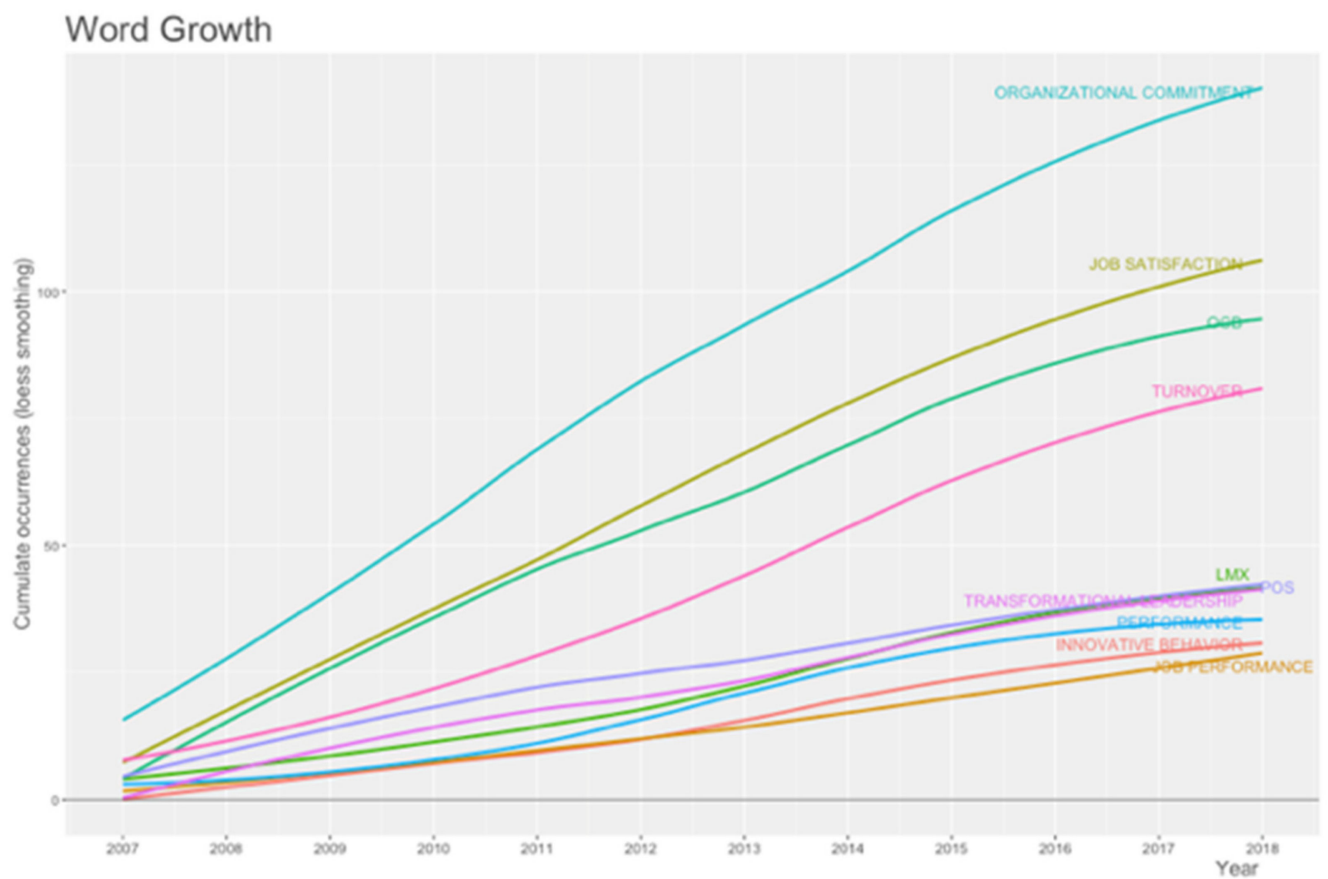

(b) word growth of top 10 keywords by yearly cumulation

Figure 2. Word growth trend by year (single year based and yearly cumulation of keywords). Note: These figures were generated using the Bibliometrix package in R software. Due to the size of the figure and page layout, the image may not be clear. For access to the high-quality version of these figures, please visit the following website: (2-a) https://figshare.com/s/5b34d5cad0bf01e2228b, (2-b) https://figshare.com/s/c24de8f578cb99d60d7e. 


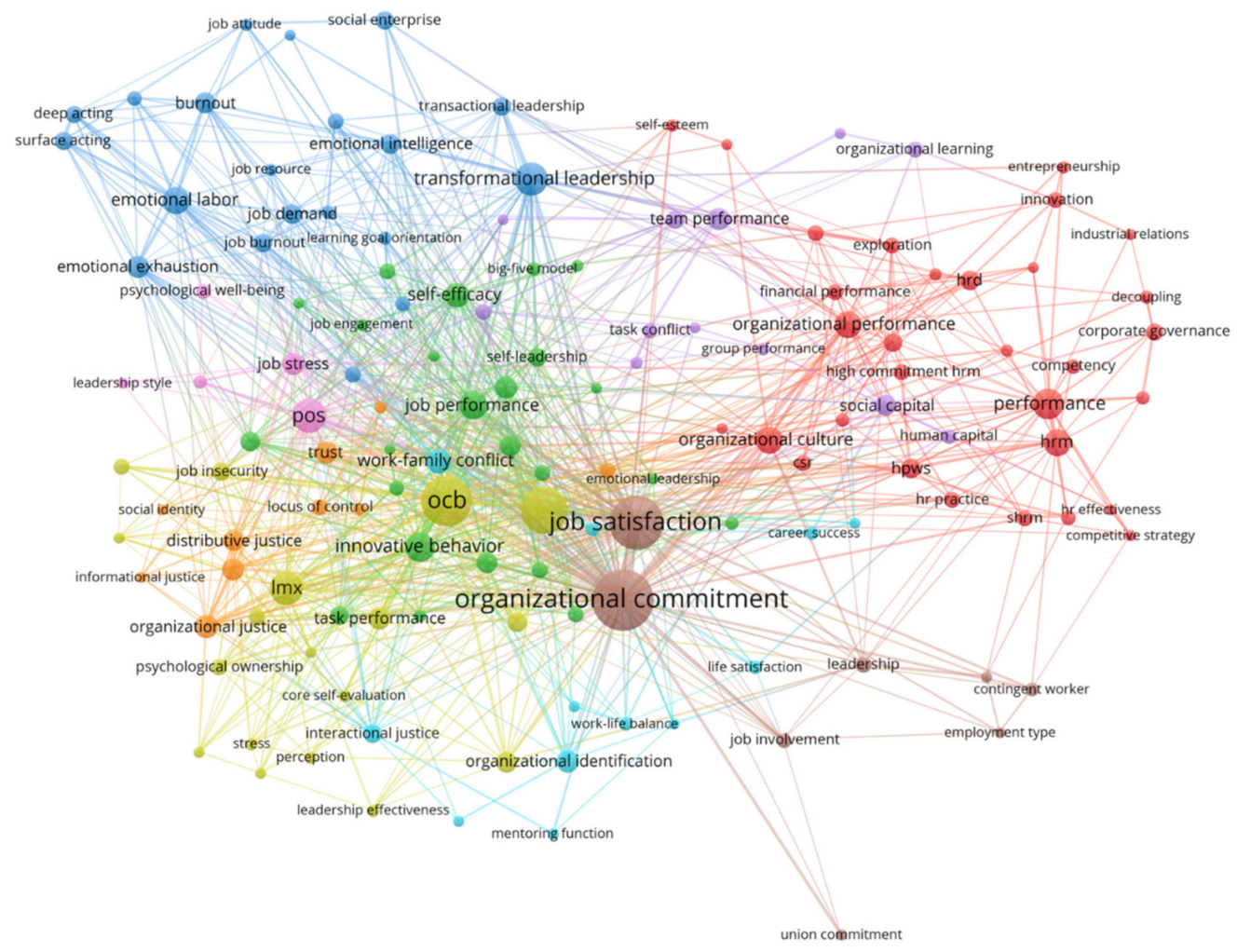

Figure 3. Korean HRM studies thematic map. Note: This figure was generated using VOSviewer software. Due to the size of the figure and page layout, the image may not be clear. For access to the high-quality version of this figure, please visit the following website: https:/figshare.com/s/ $6 \mathrm{e} 44 \mathrm{e} 07 \mathrm{f} 8333 \mathrm{c} 4013439$.

\subsection{Keyword Level Analysis}

Table 7 presents a list of the top ten most frequently occurred keywords and the associated network level indicators of the keywords. Organizational commitment was the most frequently occurring keywords and was more connected with other keywords in the list. The frequency rank of organizational commitment, job satisfaction, organizational citizenship behavior, turnover, innovative behavior, job performance is correspondent to the degree centrality rank, but the frequency ranks of perceived organizational support, transformational leadership, leader-member exchange, and performance are not matched with degree centrality. This discrepancy indicates there are keywords that occurred relatively infrequently; they have a tendency of connection with more keywords than the other keywords do.

\subsection{Ego-centric Level Analysis}

Dominant keyword in this study was selected based on keywords frequency. Ego-centric network were extracted from the whole network, and then the title keyword was removed. For example, in job performance's ego-centric network, keywords that has direct connection with job performance were selected and extracted, and then job performance was deleted. The selected keywords are organizational commitment, job satisfaction, turnover, organizational citizenship behavior (OCB), performance, transformational leadership, POS, leader-member Exchange (LMX), innovative behavior, and job performance. Figures 4-13 provide details of prominent keywords' ego-centric network profiles. 
Table 6. Keywords cluster.

\begin{tabular}{|c|c|c|c|c|c|c|c|c|}
\hline $\begin{array}{l}\text { Cluster } 1 \\
\text { Strategic HRM (Red) }\end{array}$ & $\begin{array}{c}\text { Cluster 2 } \\
\text { Creativity and } \\
\text { Innovation (Green) }\end{array}$ & $\begin{array}{c}\text { Cluster } 3 \\
\text { Employee Emotional } \\
\text { Issue (Blue) }\end{array}$ & $\begin{array}{c}\text { Cluster } 4 \\
\text { Relationship and } \\
\text { Attachment (Yellow) }\end{array}$ & $\begin{array}{c}\text { Cluster } 5 \\
\text { Group Dynamics } \\
\text { (Magenta) }\end{array}$ & $\begin{array}{c}\text { Cluster } 6 \\
\text { Career Issue (Auqa) }\end{array}$ & $\begin{array}{c}\text { Cluster } 7 \\
\text { Fairness and Justice } \\
\text { in Organization } \\
\text { (Orange) }\end{array}$ & $\begin{array}{c}\text { Cluster } 8 \\
\text { Commitment and } \\
\text { Satisfaction (Brown) }\end{array}$ & $\begin{array}{c}\text { Cluster } 9 \\
\text { Organizational } \\
\text { Support (Pink) }\end{array}$ \\
\hline performance & innovative behavior & $\begin{array}{l}\text { transformational } \\
\text { leadership }\end{array}$ & $\begin{array}{l}\text { organization } \\
\text { citizenship behavior } \\
\text { (OCB) }\end{array}$ & team performance & work-family conflict & organizational justice & $\begin{array}{c}\text { organizational } \\
\text { commitment }\end{array}$ & $\begin{array}{l}\text { perceived } \\
\text { organizational } \\
\text { support (POS) }\end{array}$ \\
\hline $\begin{array}{c}\text { human resource } \\
\text { management (HRM) }\end{array}$ & job performance & emotional labor & turnover & social capital & $\begin{array}{l}\text { organizational } \\
\text { identification }\end{array}$ & procedural justice & job satisfaction & job stress \\
\hline organizational culture & self-efficacy & emotional exhaustion & $\begin{array}{l}\text { leader member } \\
\text { exchange (LMX) }\end{array}$ & social network & interactional justice & trust & leadership & $\begin{array}{l}\text { psychological } \\
\text { well-being }\end{array}$ \\
\hline $\begin{array}{c}\text { organizational } \\
\text { performance }\end{array}$ & creativity & burnout & task performance & $\begin{array}{l}\text { organizational } \\
\text { learning }\end{array}$ & career commitment & distributive justice & job involvement & customer orientation \\
\hline $\begin{array}{l}\text { high performance work } \\
\text { system (HPWS) }\end{array}$ & $\begin{array}{l}\text { psychological } \\
\text { empowerment }\end{array}$ & job demand & ethical leadership & trust in leader & career success & $\begin{array}{l}\text { organizational } \\
\text { effectiveness }\end{array}$ & contingent worker & leadership style \\
\hline $\begin{array}{c}\text { human resource } \\
\text { development (HRD) }\end{array}$ & authentic leadership & emotional intelligence & job characteristic & human capital & life satisfaction & locus of control & employee satisfaction & \\
\hline $\begin{array}{l}\text { small and medium } \\
\text { enterprise (SME) }\end{array}$ & job autonomy & job burnout & job insecurity & task conflict & work-life balance & empowerment & employment type & \\
\hline $\begin{array}{l}\text { corporate governance } \\
\text { corporate social } \\
\text { responsibility (CSR) }\end{array}$ & $\begin{array}{l}\text { abusive supervision } \\
\text { self-leadership }\end{array}$ & $\begin{array}{l}\text { social enterprise } \\
\text { surface acting }\end{array}$ & $\begin{array}{l}\text { affective commitment } \\
\text { organizational trust }\end{array}$ & $\begin{array}{l}\text { group performance } \\
\text { relationship conflict }\end{array}$ & $\begin{array}{l}\text { job commitment } \\
\text { job crafting }\end{array}$ & $\begin{array}{c}\text { personality } \\
\text { informational justice }\end{array}$ & union commitment & \\
\hline exploration & $\begin{array}{l}\text { empowering } \\
\text { leadership }\end{array}$ & $\begin{array}{l}\text { transactional } \\
\text { leadership }\end{array}$ & $\begin{array}{l}\text { psychological } \\
\text { ownership }\end{array}$ & group efficacy & mentoring & social identity & & \\
\hline $\begin{array}{l}\text { exploration and } \\
\text { exploitation }\end{array}$ & $\begin{array}{c}\text { positive } \\
\text { psychological capital } \\
\text { (PsyCap) }\end{array}$ & deep acting & core self-evaluation & organization theory & mentoring function & & & \\
\hline financial performance & adaptive performance & social support & $\begin{array}{l}\text { leadership } \\
\text { effectiveness }\end{array}$ & social relationship & $\begin{array}{l}\text { psychological } \\
\text { contract }\end{array}$ & & & \\
\hline $\begin{array}{l}\text { high commitment HRM } \\
\text { human resource (HR) }\end{array}$ & intrinsic motivation & servant leadership & perception & & & & & \\
\hline $\begin{array}{c}\text { human resource }(\mathrm{HR}) \\
\text { practice }\end{array}$ & work engagement & emotional dissonance & stress & & & & & \\
\hline innovation & big-five model & goal orientation & $\begin{array}{l}\text { individualism vs } \\
\text { collectivism }\end{array}$ & & & & & \\
\hline
\end{tabular}


Table 6. Cont

\begin{tabular}{|c|c|c|c|c|c|c|c|c|}
\hline $\begin{array}{c}\text { Cluster } 1 \\
\text { Strategic HRM (Red) }\end{array}$ & $\begin{array}{c}\text { Cluster } 2 \\
\text { Creativity and } \\
\text { Innovation (Green) }\end{array}$ & $\begin{array}{c}\text { Cluster } 3 \\
\text { Employee Emotional } \\
\text { Issue (Blue) }\end{array}$ & $\begin{array}{c}\text { Cluster } 4 \\
\text { Relationship and } \\
\text { Attachment (Yellow) }\end{array}$ & $\begin{array}{c}\text { Cluster } 5 \\
\text { Group Dynamics } \\
\text { (Magenta) }\end{array}$ & $\begin{array}{c}\text { Cluster } 6 \\
\text { Career Issue (Auqa) }\end{array}$ & $\begin{array}{c}\text { Cluster } 7 \\
\text { Fairness and Justice } \\
\text { in Organization } \\
\text { (Orange) }\end{array}$ & $\begin{array}{c}\text { Cluster } 8 \\
\text { Commitment and } \\
\text { Satisfaction (Brown) }\end{array}$ & $\begin{array}{c}\text { Cluster } 9 \\
\text { Organizational } \\
\text { Support (Pink) }\end{array}$ \\
\hline $\begin{array}{l}\text { strategic human resource } \\
\text { management (SHRM) }\end{array}$ & knowledge sharing & job control & power distance & & & & & \\
\hline competency & job engagement & $\begin{array}{l}\text { learning goal } \\
\text { orientation }\end{array}$ & supervisor trust & & & & & \\
\hline $\begin{array}{l}\text { performance-based } \\
\text { agency theory }\end{array}$ & $\begin{array}{l}\text { psychological safety } \\
\text { trust in supervisor }\end{array}$ & $\begin{array}{l}\text { job attitude } \\
\text { job resource }\end{array}$ & trait activation theory & & & & & \\
\hline $\begin{array}{c}\text { decoupling } \\
\text { knowledge management }\end{array}$ & coaching & workplace spirituality & & & & & & \\
\hline $\begin{array}{l}\text { knowledge management } \\
\text { employability }\end{array}$ & $\begin{array}{l}\text { emotional leadership } \\
\text { in-role performance }\end{array}$ & & & & & & & \\
\hline entrepreneurship & $\begin{array}{c}\text { positive } \\
\text { psychological capital }\end{array}$ & & & & & & & \\
\hline $\begin{array}{l}\text { learning organization } \\
\text { self-esteem } \\
\text { competitive strategy }\end{array}$ & proactive behavior & & & & & & & \\
\hline $\begin{array}{l}\text { education and training } \\
\text { evaluation }\end{array}$ & & & & & & & & \\
\hline HR effectiveness & & & & & & & & \\
\hline industrial relations & & & & & & & & \\
\hline strategic leadership & & & & & & & & \\
\hline
\end{tabular}


Table 7. Prominent keyword list and network indicator.

\begin{tabular}{cccc}
\hline Rank by Frequency & Keywords & Frequency & Degree Centrality \\
\hline 1 & ORGANIZATIONAL COMMITMENT & 138 & 303 \\
2 & JOB SATISFACTION & 106 & 258 \\
3 & OCB & 93 & 197 \\
4 & TURNOVER & 80 & 202 \\
5 & POS & 42 & 110 \\
6 & LRANSFORMATIONAL LEADERSHIP & 41 & 116 \\
7 & LERXORMANCE & 41 & 109 \\
8 & INNOVATIVE BEHAVIOR & 35 & 122 \\
9 & JOB PERFORMANCE & 31 & 84 \\
10 & & 29 & 83 \\
\hline
\end{tabular}

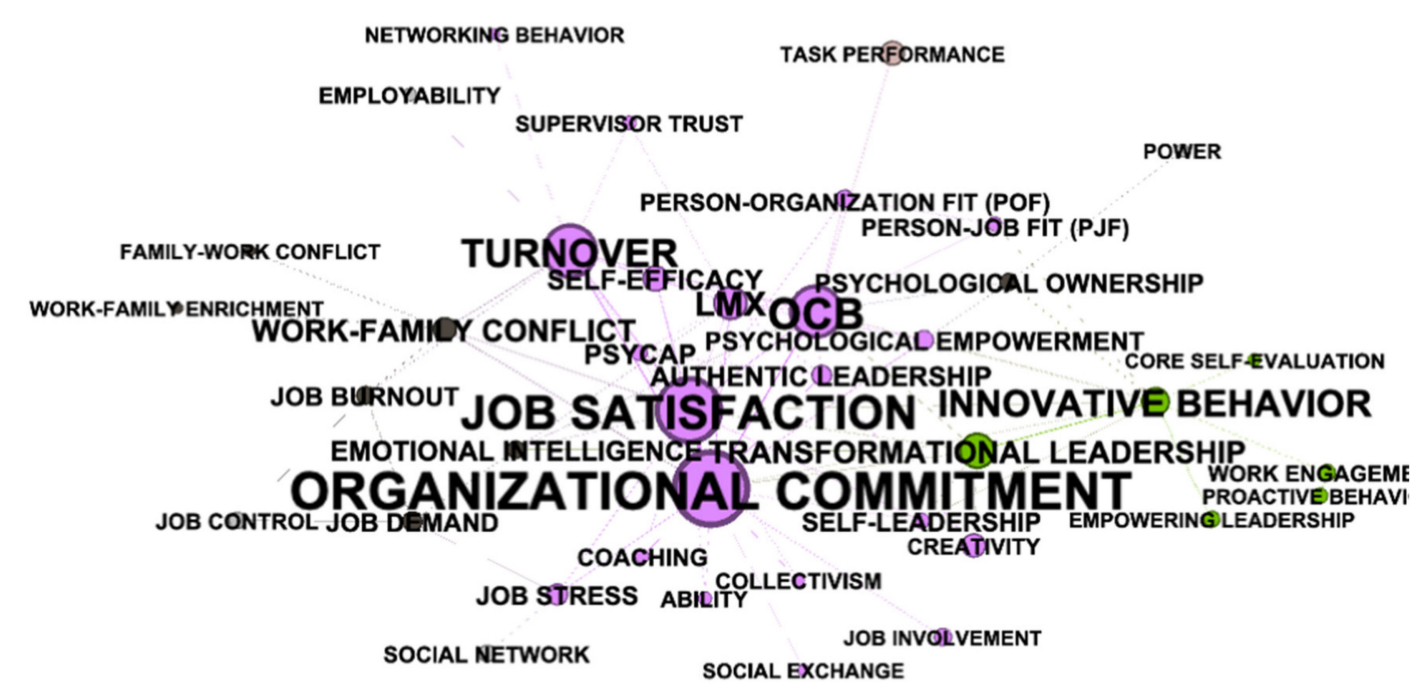

Top 10 Keywords in ego-centric network

\begin{tabular}{cc}
\hline Keywords & Degree centrality \\
\hline ORGANIZATIONAL COMMITMENT & 19 \\
JOB SATISFACTION & 16 \\
OCB & 14 \\
TURNOVER & 11 \\
INNOVATIVE BEHAVIOR & 11 \\
LMX & 9 \\
TRANSFORMATIONAL LEADERSHIP & 7 \\
WORK-FAMILY CONFLICT & 6 \\
EMOTIONAL INTELLIGENCE & 5 \\
PSYCAP & 5 \\
\hline
\end{tabular}

Figure 4. Ego-network of job performance. Note: This figure was generated using network graph software Gephi. This ego-centric network figure is a simplified version with ego's keywords, which link's weight is higher than two. 


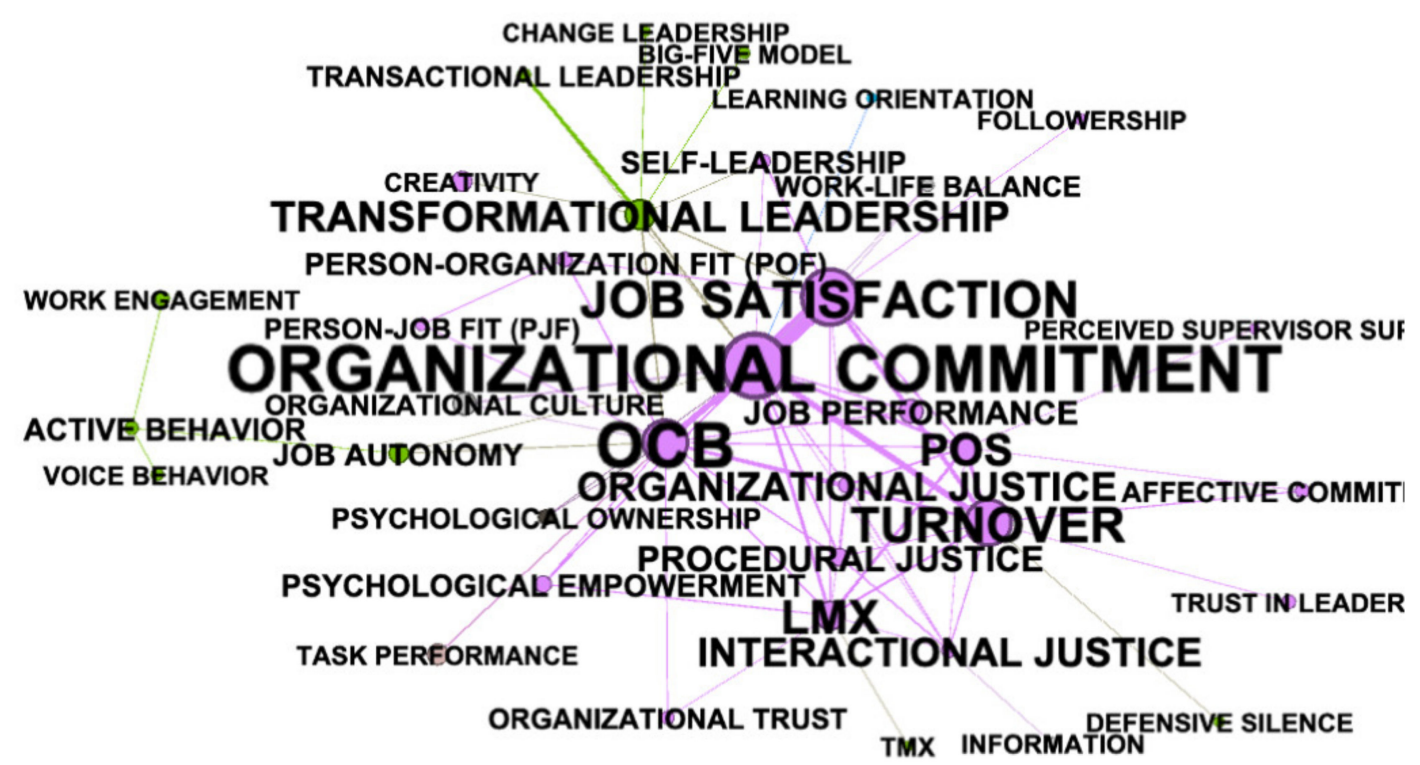

Top 10 Keywords in ego-centric network

\begin{tabular}{cc}
\hline Keywords & Degree centrality \\
\hline ORGANIZATIONAL COMMITMENT & 18 \\
OCB & 17 \\
JOB SATISFACTION & 12 \\
TURNOVER & 11 \\
LMX & 10 \\
POS & 9 \\
TRANSFORMATIONAL LEADERSHIP & 8 \\
INTERACTIONAL JUSTICE & 7 \\
ORGANIZATIONAL JUSTICE & 7 \\
PROCEDURAL JUSTICE & 5 \\
\hline
\end{tabular}

Figure 5. Ego-network of innovative behavior. Note: This figure was generated using network graph software Gephi. This ego-centric network figure is a simplified version with ego's keywords, which link's weight is higher than two. 


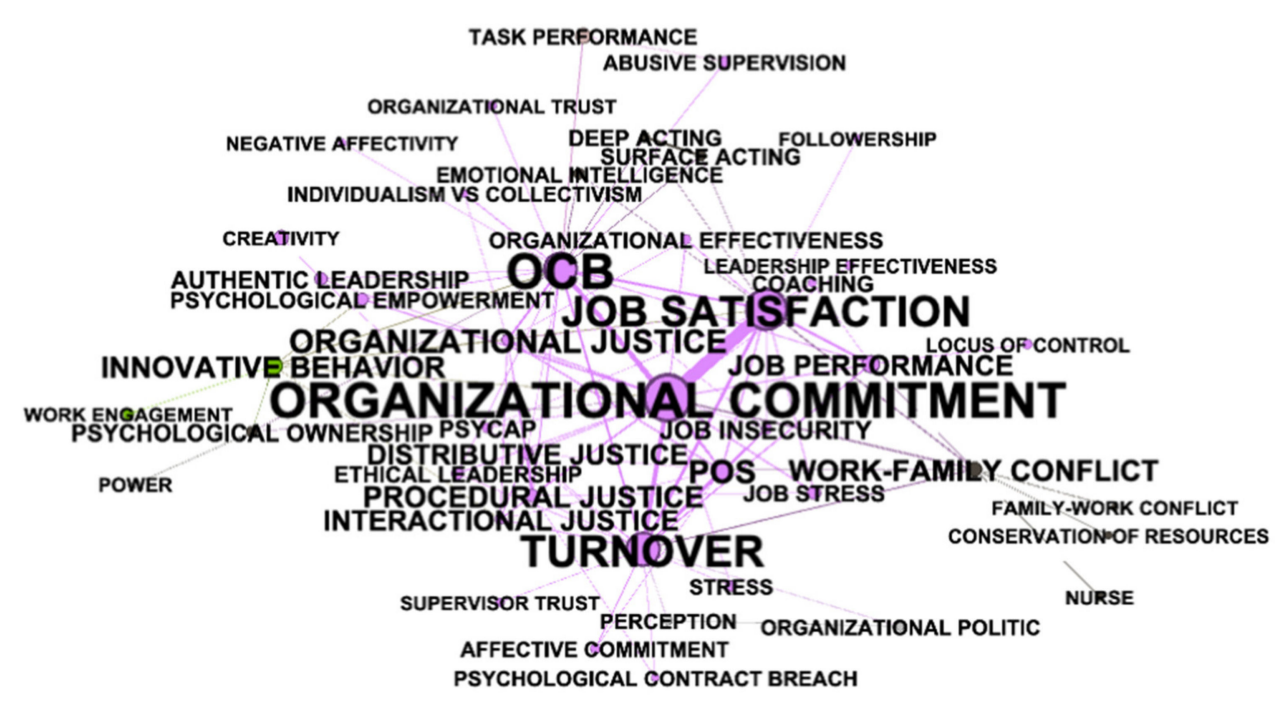

Top 10 Keywords in ego-centric network

\begin{tabular}{cc}
\hline Keywords & Degree centrality \\
\hline ORGANIZATIONAL COMMITMENT & 22 \\
OCB & 22 \\
TURNOVER & 18 \\
JOB SATISFACTION & 17 \\
POS & 10 \\
ORGANIZATIONAL JUSTICE & 10 \\
WORK-FAMILY CONFLICT & 8 \\
PROCEDURAL JUSTICE & 8 \\
INNOVATIVE BEHAVIOR & 8 \\
JOB PERFORMANCE & 7 \\
\hline
\end{tabular}

Figure 6. Ego-network of LMX. Note: This figure was generated using network graph software Gephi. This ego-centric network figure is a simplified version with ego's keywords, which link's weight is higher than two. 


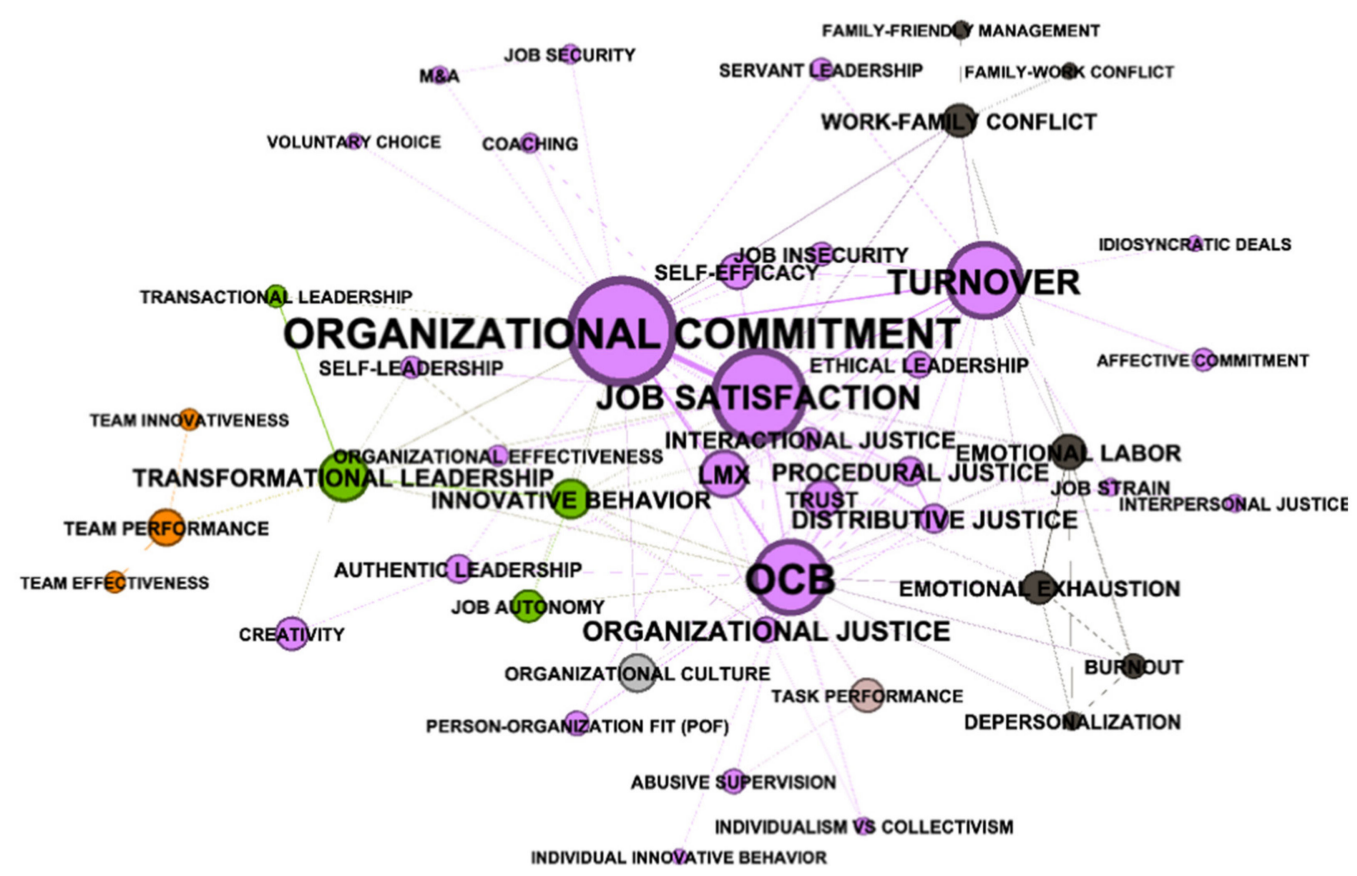

Top 10 Keywords in ego-centric network

\begin{tabular}{cc}
\hline Keywords & Degree centrality \\
\hline ORGANIZATIONAL COMMITMENT & 25 \\
OCB & 25 \\
TURNOVER & 18 \\
JOB SATISFACTION & 17 \\
ORGANIZATIONAL JUSTICE & 11 \\
LMX & 9 \\
DISTRIBUTIVE JUSTICE & 9 \\
TRANSFORMATIONAL LEADERSHIP & 8 \\
PROCEDURAL JUSTICE & 8 \\
INNOVATIVE BEHAVIOR & 8 \\
\hline
\end{tabular}

Figure 7. Ego-network of POS. Note: This figure was generated using network graph software Gephi. This ego-centric network figure is a simplified version with ego's keywords, which link's weight is higher than two. 


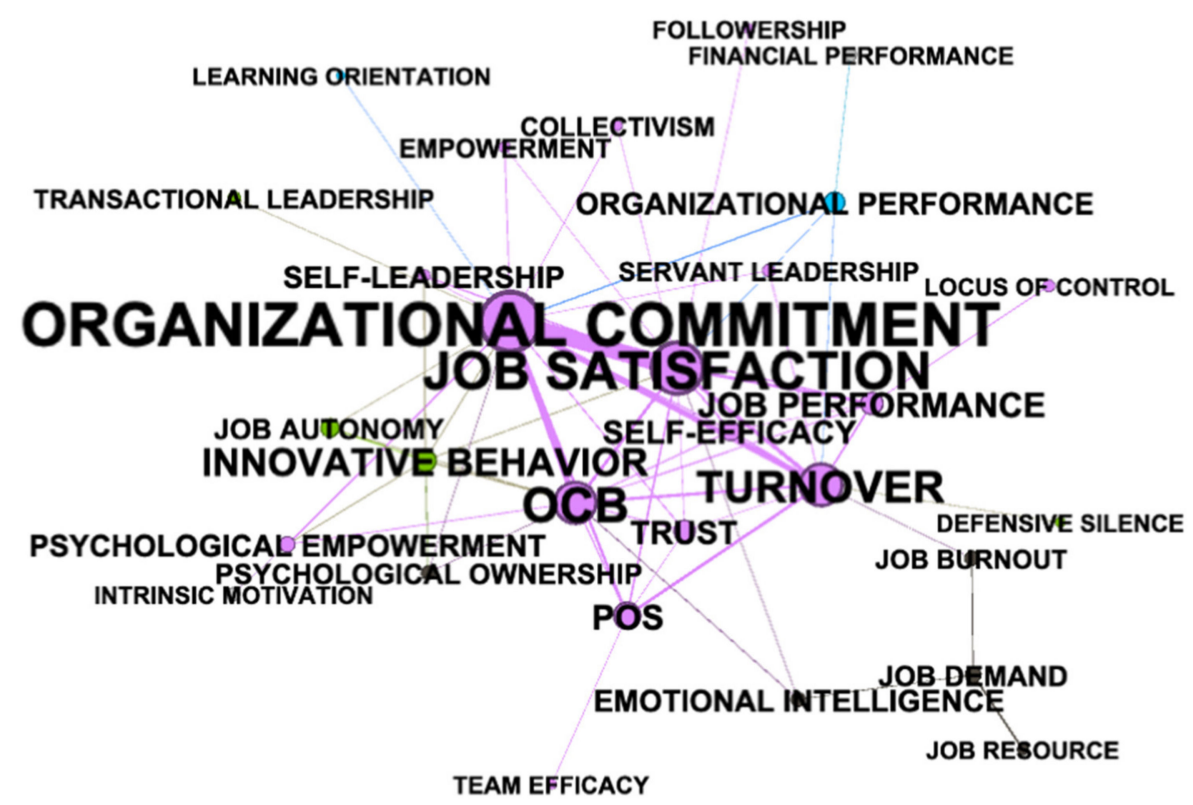

Top 10 Keywords in ego-centric network

\begin{tabular}{cc}
\hline Keywords & Degree centrality \\
\hline ORGANIZATIONAL COMMITMENT & 18 \\
JOB SATISFACTION & 14 \\
OCB & 12 \\
TURNOVER & 11 \\
INNOVATIVE BEHAVIOR & 7 \\
JOB PERFORMANCE & 6 \\
POS & 6 \\
TRUST & 5 \\
SELF-EFFICACY & 5 \\
PSYCHOLOGICALEMPOWERMENT & 4 \\
\hline
\end{tabular}

Figure 8. Ego-network of transformational leadership. Note: This figure was generated using network graph software Gephi. This ego-centric network figure is a simplified version with ego's keywords, which link's weight is higher than two. 


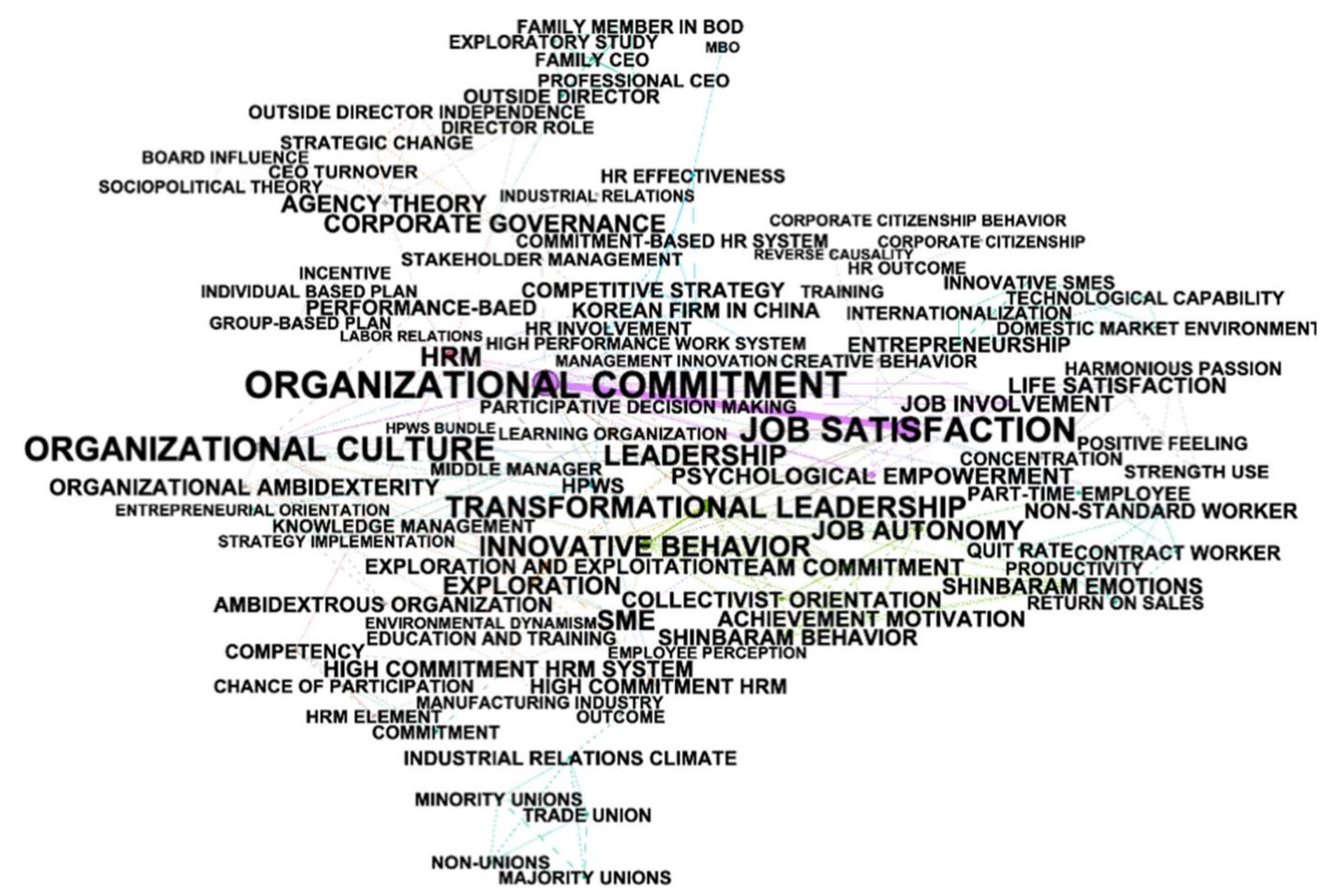

Top 10 Keywords in ego-centric network

\begin{tabular}{cc}
\hline Keywords & Degree centrality \\
\hline ORGANIZATIONAL COMMITMENT & 19 \\
JOB SATISFACTION & 17 \\
ORGANIZATIONAL CULTURE & 16 \\
TRANSFORMATIONAL LEADERSHIP & 13 \\
LEADERSHIP & 12 \\
INNOVATIVE BEHAVIOR & 12 \\
HRM & 11 \\
SME & 11 \\
JOB AUTONOMY & 10 \\
CORPORATE GOVERNANCE & 9 \\
\hline
\end{tabular}

Figure 9. Ego-network of performance. Note: This figure was generated using network graph software Gephi. This ego-centric network figure is a simplified version with ego's keywords, which link's weight is higher than two. 


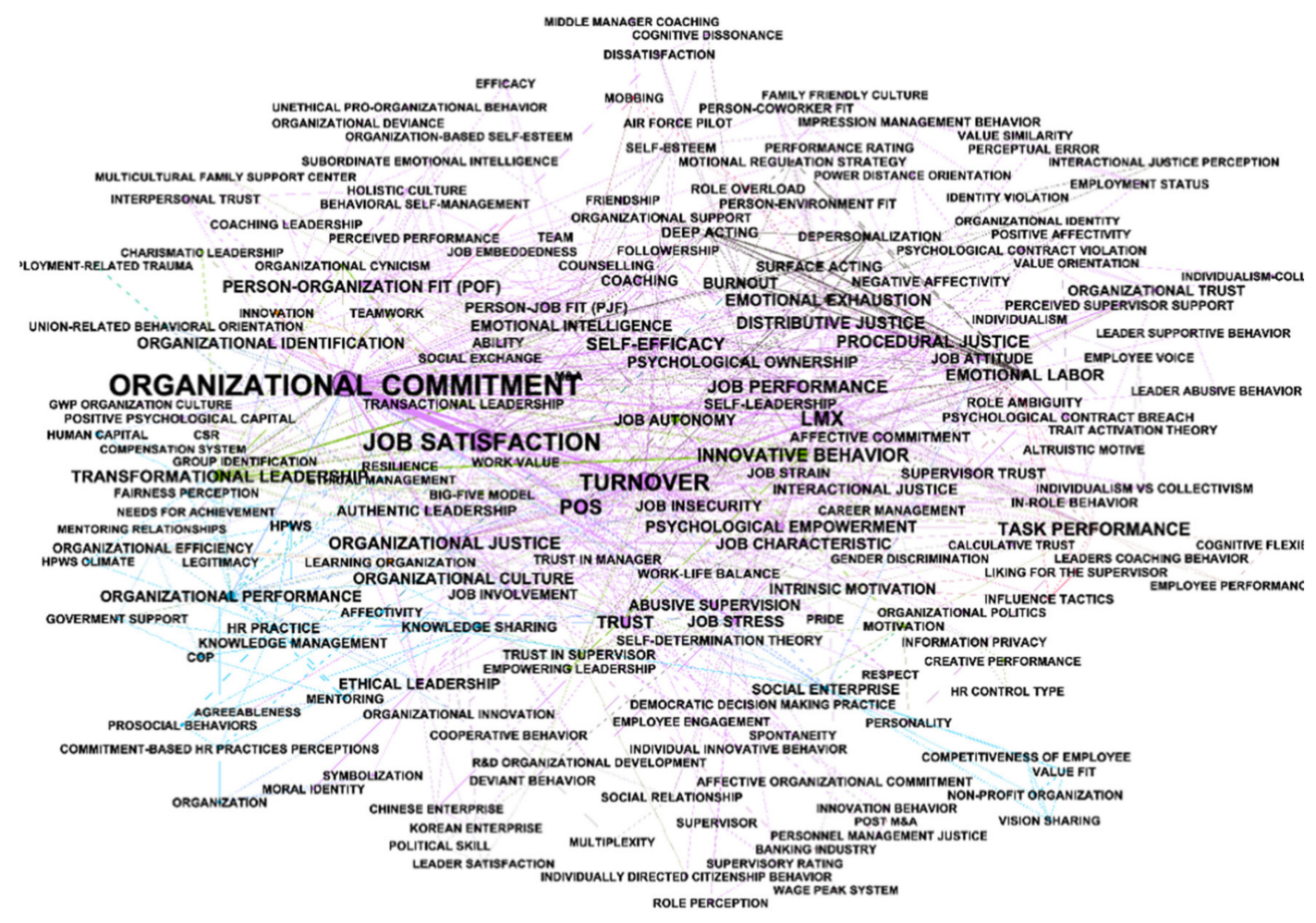

Top 10 Keywords in ego-centric network

\begin{tabular}{cc}
\hline Keywords & Degree centrality \\
\hline ORGANIZATIONAL COMMITMENT & 84 \\
JOB SATISFACTION & 62 \\
TURNOVER & 56 \\
LMX & 44 \\
POS & 42 \\
INNOVATIVE BEHAVIOR & 32 \\
JOB PERFORMANCE & 30 \\
TASK PERFORMANCE & 30 \\
SELF-EFFICACY & 29 \\
ORGANIZATIONAL JUSTICE & 27 \\
\hline
\end{tabular}

Figure 10. Ego-network of organization citizenship behavior. Note: This figure was generated using network graph software Gephi. This ego-centric network figure is a simplified version with ego's keywords, which link's weight is higher than two. 


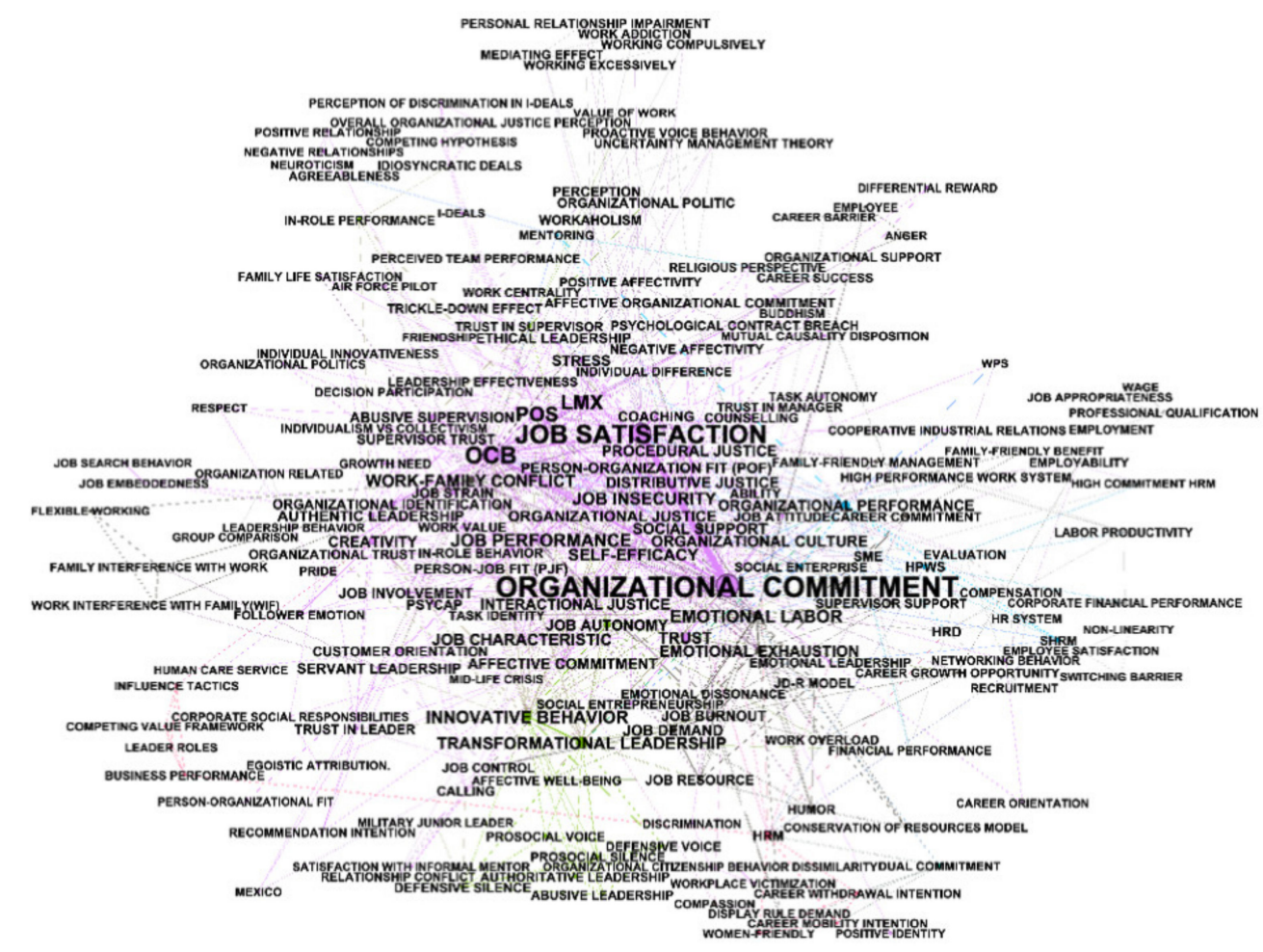

Top 10 Keywords in ego-centric network

\begin{tabular}{cc}
\hline Keywords & Degree centrality \\
\hline ORGANIZATIONAL COMMITMENT & 79 \\
JOB SATISFACTION & 67 \\
OCB & 56 \\
POS & 42 \\
LMX & 41 \\
JOB PERFORMANCE & 30 \\
EMOTIONAL LABOR & 29 \\
INNOVATIVE BEHAVIOR & 28 \\
JOB INSECURITY & 27 \\
WORK-FAMILY CONFLICT & 25 \\
\hline
\end{tabular}

Figure 11. Ego-network of turnover. Note: This figure was generated using network graph software Gephi. This ego-centric network figure is a simplified version with ego's keywords, which link's weight is higher than two. 


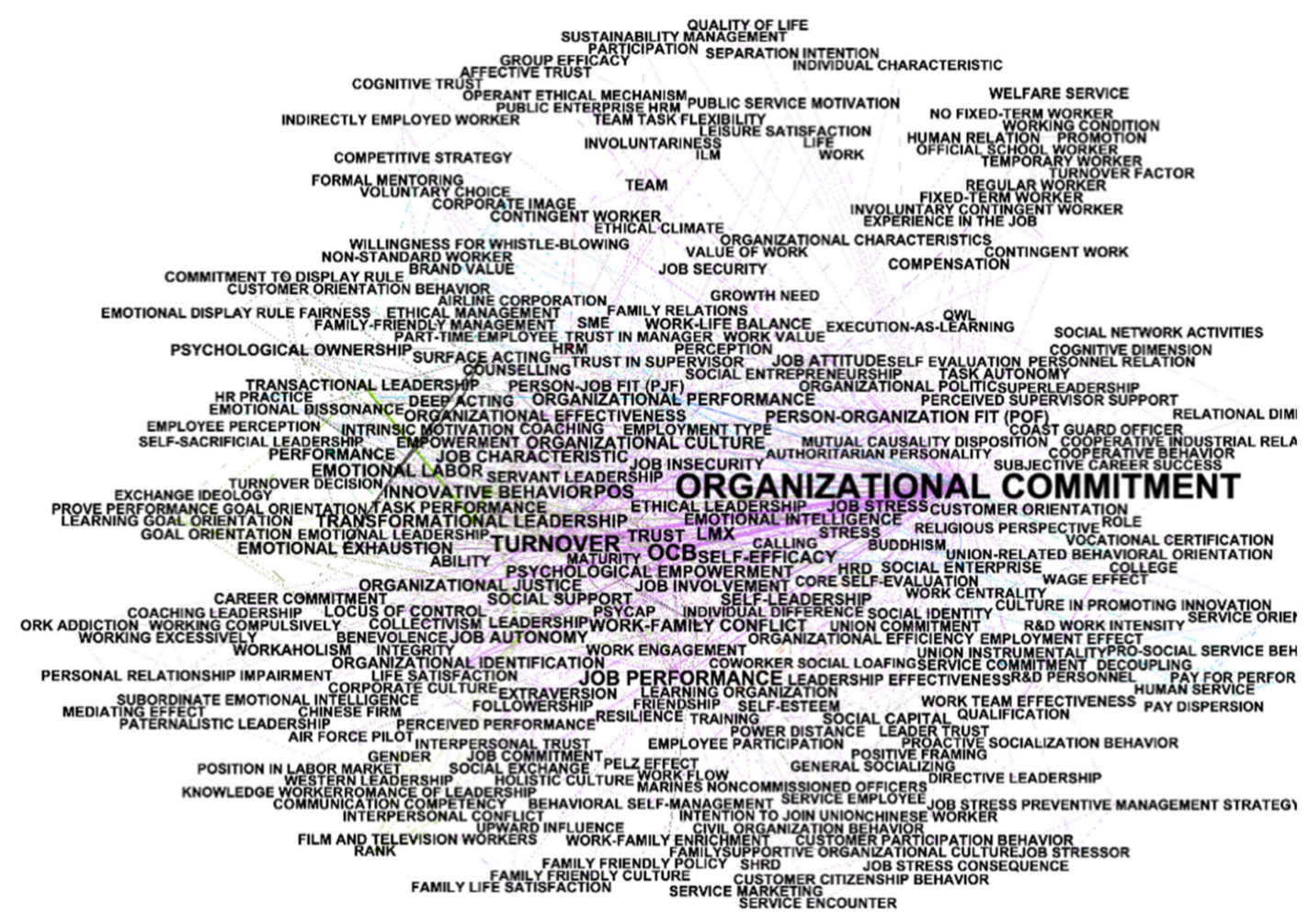

Top 10 Keywords in ego-centric network

\begin{tabular}{cc}
\hline Keywords & Degree centrality \\
\hline ORGANIZATIONAL COMMITMENT & 149 \\
TURNOVER & 67 \\
OCB & 62 \\
JOB PERFORMANCE & 44 \\
POS & 40 \\
LMX & 33 \\
INNOVATIVE BEHAVIOR & 29 \\
TRANSFORMATIONAL LEADERSHIP & 28 \\
SELF-EFFICACY & 27 \\
EMOTIONAL LABOR & 26 \\
\hline
\end{tabular}

Figure 12. Ego-network of job satisfaction. Note: This figure was generated using network graph software Gephi. This ego-centric network figure is a simplified version with ego's keywords, which link's weight is higher than two. 


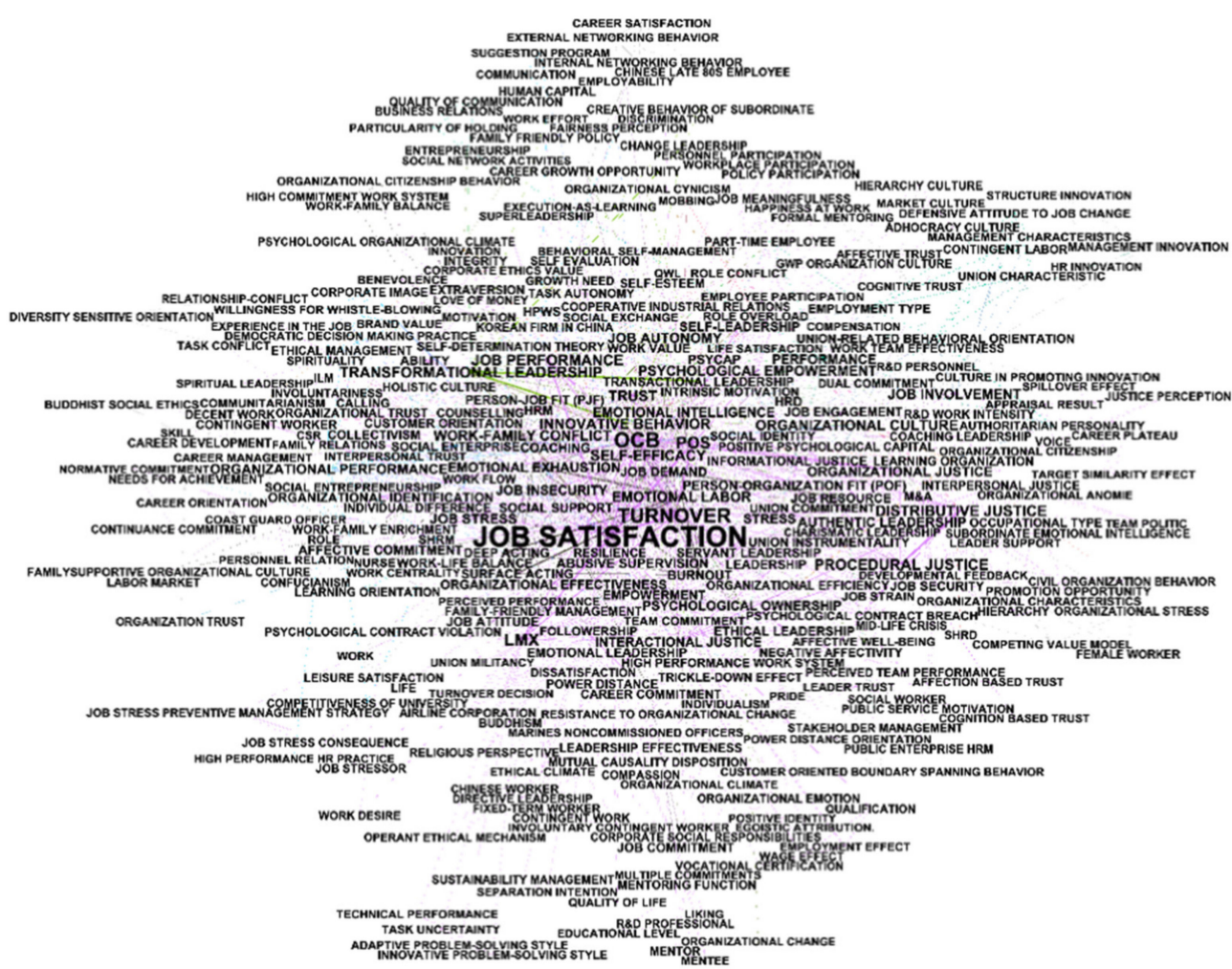

Top 10 Keywords in ego-centric network

\begin{tabular}{cc}
\hline Keywords & Degree centrality \\
\hline JOB SATISFACTION & 149 \\
OCB & 84 \\
TURNOVER & 79 \\
LMX & 47 \\
POS & 45 \\
PROCEDURAL JUSTICE & 34 \\
JOB PERFORMANCE & 33 \\
TRANSFORMATIONAL LEADERSHIP & 33 \\
DISTRIBUTIVE JUSTICE & 33 \\
TRUST & 30 \\
\hline
\end{tabular}

Figure 13. Ego-network of organizational commitment. Note: This figure was generated using network graph software Gephi. This ego-centric network figure is a simplified version with ego's keywords, which link's weight is higher than two.

\section{Discussion and Conclusions}

Markoulli et al. [9] stated that the intuitive categorization of HRM scholarship can provide a biased and inaccurate picture of the field. Thus, mapping the research semantics that identifies thematic classification using bibliometric methods is essential. In this sense, this study provides meaningful and empirical-based research classification to extend understanding of the knowledge structure and research trends in Korean and international HRM scholarship. 


\subsection{Characteristics of Korean HRM Research Trends}

As suggested by Reference [4], the commonly accepted HRM research classification in Korea is categorized into six: organizational behavior, organizational theory, personnel management, industrial relations, strategic management, and research methodology. All keywords clusters found in this study besides SHRM seems to belong to the organizational behavior category classification. Organizational behavior is often categorized into sub-clusters, namely, individual difference, work attitude, leadership, motivation, social exchange, fitness, and group dynamics. We compared the clusters in this study and the classification from References [4,34]. Some clusters in this study have a single match with [34]'s classification, and some are matched with multiple classification categories.

Keyword clusters that are matched with those from Reference [34]'s Korean HRM study classification are cluster 2 (creativity and innovation), cluster 5 (group dynamics), cluster 7 (fairness and justice in an organization), cluster 8 (commitment and satisfaction), and cluster 9 (organization support). Cluster 3 (employee emotional issue), cluster 4 (relationship and attachment), and cluster 6 (career issue) are closely related to the multiple study subjects of the organizational behavior in the Korean HRM study classifications (see Table 8).

Table 8. Thematic comparison with the HRM study classification of Reference [34].

\begin{tabular}{cccc}
\hline & Clusters from this Study & & Clusters from Reference [34] \\
\hline Cluster no & Theme & Cluster no & Theme \\
\hline 1 & Strategic HRM & - & - \\
2 & Creativity and innovation & 9 & Creativity and innovation \\
& & 2 & Attitude \\
3 & Employee emotional issue & 1 & Individual Difference \\
& & Leadership \\
& & 3 & Social exchange \\
4 & Relationship and attachment & 5 & Job characteristics \\
5 & Group dynamics & 8 & Group dynamics \\
& & 7 & Attitude \\
6 & Career Issue & 2 & Social support \\
& & 5 & Motivation \\
7 & Fairness and justice in & 4 & Job characteristics \\
8 & organization & 8 & Motivation \\
9 & Commitment and satisfaction & 4 & Attitude \\
& Organization support & 2 & Social exchange \\
\hline
\end{tabular}

We can find the following changes in the Korean HRM study by comparing the clusters of this study with those of Reference [34] that analyzed Korean HRM literature from 1979 to 2008. First is the dominant emergence of SHRM. Reference [34] did not derive the theme of SHRM; however, in the present study, we classified it as the cluster containing the most extensive literature. Interest in SHRM in Korean literature has developed rapidly in recent decades. Second, interest in creativity and innovation has increased in the last decade. In Reference [34], creativity and innovation were the ninth cluster, whereas in this study, they were classified as the second cluster. This change is thought to be the result of the shift of the Korean HR system and reward system toward a more flexible and performance-oriented system [32], which has led researchers' attention to more valuable keywords, namely, creativity and innovation, in the current system. Third, Korean HRM literature still explored the attitudes of its employees, but confirmed that the focus was somewhat changed. In Reference [34], attitude focused on job satisfaction and organizational commitment was an essential topic. Meanwhile, in this study, the ranking of commitment and satisfaction cluster dropped to the eighth place. Moreover, the subject was more specifically differentiated by employee's emotional and career issues.

Most of the top ten keywords were included in other keywords' ego-centric keyword networks, indicating that highly favored dyadic or triadic relationships exist between the top-ranked keywords. In the ego-centric network of POS (Positive Organizational Support), the connections between keywords, 
such as OC (Organizational Commitment), JS (Job Satisfaction), turnover, and OCB (Organizational Citizenship Behavior) were secure. Moreover, the POS ego-centric network includes keywords that represent emotional labor, such as burnout and emotional exhaustion. Additionally, a conceptual connection exists among team performance, organizational learning, and learning organization, indicating that team and organization level learning are essential concepts in POS research. Furthermore, we found that POS has been used as an important precedent or conditional (mediation or moderation) variable in Korean HRM research. The literature related to POS in Korea shows that POS has been studied as a critical or moderating variable for the behavior of organizational members.

In the LMX (Leader-Member Exchange)'s ego-centric keyword network, OCB was the most dominant keyword that has the most connection with others. A conceptual structure that represents psychological empowerment or psychological ownership was observed. This sub-cluster is closely connected with keywords (such as innovative behavior, job performance, task performance, organizational commitment, turnover, and job satisfaction) indicating that LMX has been used often in research that identifies the psychological mechanisms for organization member's positive performance.

In the case of innovative behavior ego-centric keyword network, a thematic sub-network structure that represents innovative behavior in team and group context was determined by connecting with keywords, such as team commitment and team performance. Additionally, we observed a thematic sub-structure that reflects innovative behavior in an individual level. This thematic structure includes job characteristics, task performance, proactive behavior, and creativity. Furthermore, we found that organizational commitment, turnover intention, and job satisfaction were important keywords in the innovative behavior's ego-centric network.

\subsection{Comparison between Korean and Global HRM Research Trends}

Ego-level and thematic analyses using keyword clustering showed that most of the keywords are associated with the area of organizational behavior $(\mathrm{OB})$. Reference [9] reported that similar phenomena are observed in HRM research trends in the global context. This finding implies that OB-related concepts are at the center of Korean HRM studies. In the ego-level analysis, most OB-related keywords are more prominent and denser than the ego-networks of other keywords are. The top ten keywords based on the frequency and the degree centrality are organizational commitment, job satisfaction, turnover, organizational citizenship behavior, performance, transformational leadership, perceived organizational support, leader-member exchange, innovative behavior, and job performance. This indicates that HRM research in Korea tends to be concentrated mainly in organizational behavior in thematic and keywords level.

There are previous studies on HRM research trends in the global context that identified major topic areas of the field using bibliometric methods [8,9,22]. Reference [9] presented the following five topic clusters: strategic HRM, experiencing HRM, employment relations, international HRM, and assessing people. The thematic clusters in the present study share similarity with these five topics. First, both studies included keywords related to performance, human resources, and training and development as commonly shared keywords. The most relevant keyword in both topics was strategic human resource management (SHRM), indicating a common interest and importance of SHRM for the HRM research community in the global and Korean context. One notable difference is that HR-system-related keywords are fewer in the thematic clusters than in SHRM clusters, revealing relatively little interest in the relationship between performance and system in the Korean HRM community. Only a few keywords are related to international and critical HRM in Korean HRM research, which may reflect the Korean organization culture that represents a conservative perception of Korea's non-internationalized labor market characteristics.

Clusters in this study include more diverse keywords compared with the findings of Reference [8], which is likely due to their choice of analyzing a single IJHRM journal. Their ten clusters were distributed in cluster 1 (SHRM), cluster 4 (relationship and attachment), and cluster 9 (organizational support) among the nine clusters of this present study. Cluster 1 (strategic HRM) shows a high degree 
of similarity with [8]'s clusters 6 and 9. Keywords, such as international HRM, multinational issues, and expatriate, were important subjects in both References $[8,9]$ — but the findings from this study proposed that Korean HRM research should focus more on global and critical HRM issues to extend the research field.

Although [22] is limited because it only analyzes a single journal, their findings are still comparable with ours because [22] used factor analysis based on clustering for bibliometric data. HR and performance clusters were matched with multiple clusters from this study. Moreover, culture and motivation areas were matched with cluster 2 (creativity and innovation). The SHRM area from Reference [22] showed a high degree of similarity with cluster 1 (SHRM) in this present study. The comparison with the previous research findings confirmed that Korean HRM has shown very little interest in international HRM and multinational issues, suggesting the need to pursue the diversity of research subjects for the future development of Korean HRM academia.

Compared to HR-related disciplines, such as HRD (Human Resource Development) [14,48,49], findings from this study showed that HRM and HRD disciplines have common keywords. Moreover, top keywords between the HRM and HRD field share a level of similarity. For example, Reference [50] utilizes four keywords that are matched with the top ten keywords in this study (job satisfaction, organizational commitment, turnover intention, and transformational leadership). Three of the top ten keywords from Reference [49] also matched with the top ten keywords in this study (organization commitment, job satisfaction, performance). Reference [48] also include three keywords from the top ten keywords (transformational leadership, innovative behavior). Additionally, four keywords (transformational leadership, organization commitment, job satisfaction, and performance) from Reference [51] also matched with the top ten keywords in this study. In summary, some keywords (such as organizational commitment, job satisfaction, (transformational) leadership, and (organizational) performance) are common in both disciplines. However, a difference existed in low-ranked keywords between HRM and HRD disciplines that may also reflect differences in the research context.

\subsection{Implications, Limitations, and Contributions of the Study}

Findings from this study provide a quantified profile and semantic structure of HRM research trends in Korea. The finding reveals that Korean HRM studies have focused more on the topics in the area of organizational behavior than other research areas, and that the Korean HRM research can be grouped into nine topic clusters. The comparison with the existing bibliometric studies of HRM research trends in the global context shows the intensive interest in the area of organizational behavior. Moreover, several clusters of research keywords, such as SHRM, show similar trends in both Korea and international HRM communities. Meanwhile, the areas of HR system, international HRM, and critical HRM only have fewer keywords and received less attention in Korean research.

Based on the above-mentioned research findings, several theoretical implications of this study can be discussed. Specifically, the investigation of the country-specific semantic structure of Korean HRM in the present study contributes to improving HRM research at the global level. The results provide a useful foundation of the future comparative studies between Western HRM (e.g., USA) and Asian HRM (e.g., Korea) based on the universality and uniqueness of Korean HRM research. The results of the bibliometric analysis in this study shed light on the potential subjects for the comparative HRM study. Moreover, results of the ego-level and thematic analyses using keyword clustering reveal that research topics in the area of organizational behavior (OB) are a good starting point, with which most keywords are associated, as observed in HRM research trends in the global context. Specifically, we recommend giving attention to the commonly shared keywords, such as strategic human resource management (SHRM), in the present study on Korean HRM and the prior reviews on the global HRM. Considering the works of Reference [8] that identified the individual topic clusters on country-specific HR (i.e., China) and international HRM, future researchers can conduct a comparative HRM study between countries (e.g., Korea and China) in the same region. 
Based on the results of the present study, some issues regarding the features of Korean HRM research need to be discussed. First, thematic clusters found from Korean research show their focus on process-oriented and people issues, such as job satisfaction, employee emotions, engagement, workplace relationship, etc., (soft aspects). Meanwhile, the global-level studies have emphasized the result-oriented systematic and technical topics, including job performance, employee assessment, leadership effectiveness, etc., (hard aspects). This finding suggests that research trends in Korea partly reflect the uniqueness of the local context.

Second, despite the difference above, there is a strong tendency of synchronization in terms of research topics among scholarly communities in Korea toward global ones. As evidence, much attention has been paid to strategic human resource management (SHRM), one of the popular topics in HRM research at the global level. This is a remarkable and recent change for SHRM, which was emerged as a dominant theme in Korean literature. Considering the range of literature in a global context from 1985 to 2015, HRM research in Korea shares universality, in some respects, with research in the global context. This trend of synchronization in the thematic analysis in Korean HRM is expected to be intensified as increasing topics explored by global research are being studied, validated, and applied also in Korea. For instance, managing diversity, one of the ignored topics in Korean HRM, is expected to be listed in the near future as currently, businesses in Korea are not only hiring immigrant workers, but also expanding their business domains abroad.

Third, considering the megatrends of synchronization and globalization in scholarly communities, the uniqueness and universality in Korean HRM research are likely to affect research trends at the global level. Shifting attention to people issues is not a purely unique trend in Korea. Increasing studies in Western countries have already paid attention to attitudinal issues among employees and leadership types, such as authentic and servant leadership. This trend is geared toward the synchronization and globalization of research and practices. Eventually, local and global HRM studies are projected to be integrated, which intensifies the universality of the local studies and locality of global studies.

Apart from theoretical implications, this study also has several practical implications. First, this study can be applied to training for human resource practitioners and can be used as guidance for researchers interested in HRM research trends in Korea. A common criticism of management education in Korea is the lack of details on the business environment and organization in human resource management practices. Second, the findings of this study can be useful to the academe by reflecting accurate research-related issues and semantic structure in the HRM curriculum. Third, this study can provide useful practical guidance to practitioners, graduate students, and researchers who are interested in the comparative HRM case study topics among different countries. Last but not least, this present and in-depth future studies are helpful for multi-national companies (MNCs) planning to start their business in Korea to better understand why Korean HRM has different aspects.

Proper interpretation of the findings of this study requires giving proper care to implementation. Understanding the limitations of the study helps avoid over- or under-interpretation of the findings. First, the findings and interpretation of this study are limited to the subjects of Korean HRM research. Although this study used a certified academic research database in Korea, not all HRM articles in Korean and international journals are included. Thus, the findings of this study are limited in the current collection of three top HRM journals in Korea. Second, the result of this study does not take the exact quantitative statistical modeling approach. This study utilizes a simple comparison with previous research results. Last, the findings of this study are based on cumulated keyword data. From a dynamic perspective, the timely changing aspect of semantic structure would be beneficial to identify emerging and decreasing research concepts and subjects.

Although we captured timely changed characteristics of top 10 keywords (see Figure 14), interpretation on this issue need further investigation to answer the following questions related to the evolution of discipline: (a) Did the trends and thematic clusters in the field of HRM change over the past 10 years? (b) Are the research threads realized in the longer time perspectives? (c) Is the "density" on the HRM research fashionable? 

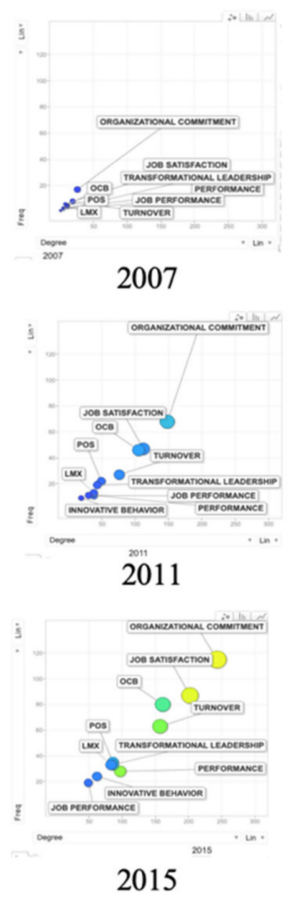
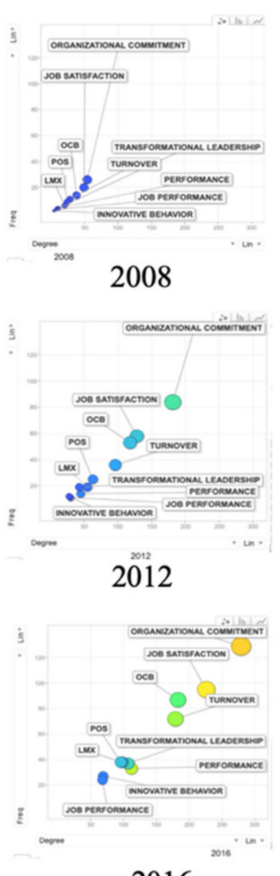

2016
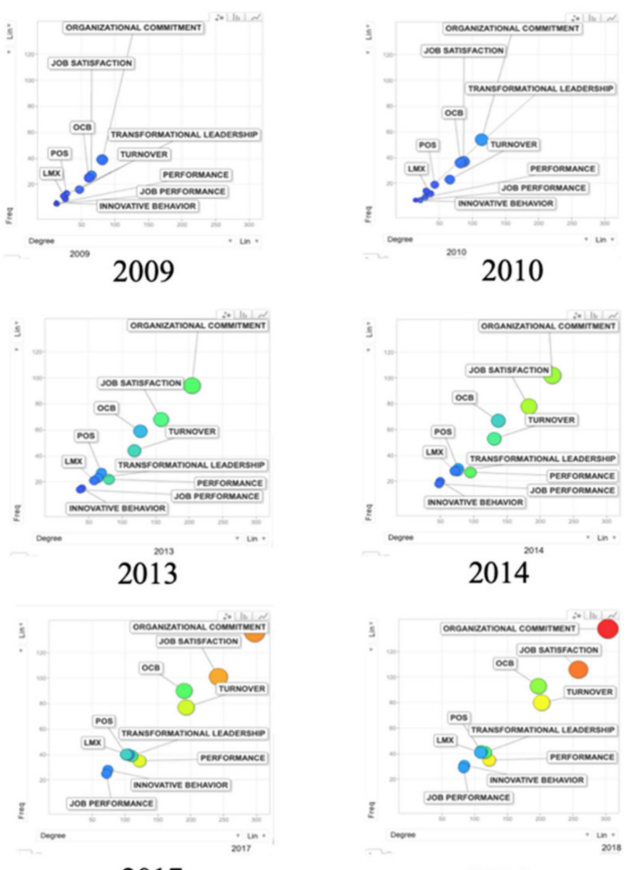

2017

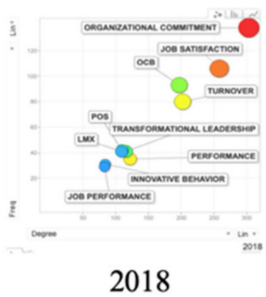

Figure 14. Timely changing characteristics on top 10 frequently used keywords. Note: This graph was generated using $\mathrm{R}$ software. Due to the size of the figure and page layout, the image may not be clear. For access to the high-quality version of this figure, please visit the following website: https://figshare.com/s/8d82d88dacc5fcc1bbff.

Thus, further research needs to collect data from a more diverse database to extend the semantic structure map of Korean HRM research. Moreover, they need to design a comparative study between two or multiple countries. Additionally, advanced research methods dealing with timely changing dynamics that explain sustainability and formation of discipline should be implied.

The present study contributes to the HRM field both in the global and Korean contexts by answering the research questions raised in the introduction section. The first research question regarding interesting topics and keywords studied among researchers in Korea was addressed through the keyword network analysis of HRM journals in Korea. The second research question regarding the implications of this study drawn from the uniqueness and universality of Korean HRM research was closely examined in the discussion section. The third research question regarding the contribution of the "country-specific" semantic structure of Korean HRM in improving HRM research at the global level was answered through the useful foundation of the future comparative studies between Western HRM (e.g., USA) and Asian HRM (e.g., Korea).

Although several limitations of this study were presented, the contributions of the present study could not be underestimated. First, this study will expand the body of knowledge of HRM by adding the semantic structure of Korean HRM studies. This study aids in a better understanding of a wider range of HRM research foci and balances the local and global HRM issues in diverse cultural contexts. Second, by comparing the research trends between Korea and Western-centered HRM scholarship, we can capture the core issues and common knowledge-building areas in the HRM field. Furthermore, this study is expected to inform Korean and international HRM communities about the imbalanced research domains between the communities, thereby calling scholars and practitioners' attention to the neglected areas of HRM. Specifically, this study can drive Korean HRM scholars to pay more attention to the HR system, critical HRM, and international HRM issues, and thus, contribute to the growth of Korean HRM knowledge that embraces diverse aspects and broader perspectives of global HRM.

In summary, studies in Human Resource Management (HRM) in Korea have been extended by reflecting on complicated organizational issues and practices. The semantic structure provides a lens 
into how practical issues or theoretical concepts can be interpreted in a scientific field. However, studies about research trends and semantic structure have previously been closer to the qualitative and non-empirical research areas. By adopting keyword network analysis in bibliometric methods, this study provides an accurate structural interpretation of Korean HRM research practice to facilitate the sustainable development of the studies on the global HRM trends.

Author Contributions: Conceptualization, C.C. and J.R.O.; Data curation, C.C., J.-H.Y. and J.R.O.; Formal analysis, C.C. and J.R.O.; Funding acquisition, J.R.O.; Investigation, C.C., J.-H.Y., J.L. and J.R.O.; Methodology, C.C. and J.R.O.; Project administration, C.C. and J.R.O.; Resources, C.C. and J.R.O.; Software, C.C.; Supervision, C.C. and J.R.O.; Validation, C.C. and S.J.J.; Visualization, C.C.; Writing-original draft, C.C., J.-H.Y., J.L., S.J.J. and J.R.O.; Writing-review \& editing, C.C., J.-H.Y., J.L., S.J.J. and J.R.O. All authors have read and agreed to the published version of the manuscript.

Funding: This article is financially supported by the Graduate School of Public Administration at Korea University in 2020, grant number K2016621. The APC (article processing charges) was funded by the Graduate School of Public Administration at Korea University.

Conflicts of Interest: The authors declare no conflict of interest.

\section{References}

1. Hyun, Y.-S.; Cho, D.; Yoon, S.W. Landscape of human resource development research in Korea: Results from author co-citation network analysis. Hum. Resour. Dev. Int. 2015, 18, 446-463. [CrossRef]

2. Kim, Y.; Bae, J.; Yu, G.-C. Patterns and determinants of human resource management change in korean venture firms after the financial crisis. Int. J. Hum. Resour. Manag. 2013, 24, 1006-1028. [CrossRef]

3. Park, S.; Oh, S.; Lee, Y. The relationships between person-organization value fit and employee attitudes in a korean government sector. Int. J. Hum. Resour. Manag. 2018, 1-26. [CrossRef]

4. Lee, K. Evolution of organizational analysis in the korean journal of management, 1992-2007. Korean J Manag. 2008, 16, 161-211.

5. Chen, C. Mapping scientific frontiers: The quest for knowledge visualization. J. Doc. 2003, 59, 364-369.

6. Dotsika, F.; Watkins, A. Identifying potentially disruptive trends by means of keyword network analysis. Technol. Forecast. Soc. Chang. 2017, 119, 114-127. [CrossRef]

7. Zupic, I.; Čater, T. Bibliometric methods in management and organization. Organ. Res. Methods 2015, 18, 429-472. [CrossRef]

8. García-Lillo, F.; Úbeda-García, M.; Marco-Lajara, B. The intellectual structure of human resource management research: A bibliometric study of the international journal of human resource management, 2000-2012. Int. J. Hum. Resour. Manag. 2017, 28, 1786-1815. [CrossRef]

9. Markoulli, M.P.; Lee, C.I.; Byington, E.; Felps, W.A. Mapping human resource management: Reviewing the field and charting future directions. Hum. Resour. Manag. Rev. 2017, 27, 367-396. [CrossRef]

10. Shin, D.; Kim, Y.K. The current state of organization theory and strategic management research in korea: A prerequisite for the development of a k-management theory. Korean J. Manag. 2015, 23, $23-65$.

11. Yu, D.; Xu, Z.; Fujita, H. Bibliometric analysis on the evolution of applied intelligence. Appl. Intell. 2019, 49, 449-462. [CrossRef]

12. Yu, D.; Xu, Z.; Šaparauskas, J. The evolution of "technological and economic development of economy": A bibliometric analysis. Technol. Econ. Dev. Econ. 2019, 25, 369-385. [CrossRef]

13. Chae, C.; Yoon, S.W.; Jo, S.J.; Han, S.H. Structural determinants of human resource development research collaboration networks: A social-network analysis of publications between 1990 to 2014. Perform. Improv. Q. 2020, 33, 7-30. [CrossRef]

14. Han, S.-h.; Chae, C.; Han, S.J.; Yoon, S.W. Conceptual organization and identity of hrd: Analyses of evolving definitions, influence, and connections. Hum. Resour. Dev. Rev. 2017, 16, 294-319. [CrossRef]

15. Wang, G.G.; Gilley, J.W.; Sun, J.Y. The "science of hrd research" reshaping hrd research through scientometrics. Hum. Resour. Dev. Rev. 2012, 11, 500-520. [CrossRef]

16. Kaufman, B.E. The historical development of American hrm broadly viewed. Hum. Resour. Manag. Rev. 2014, 24, 196-218. [CrossRef]

17. Schuler, R.; Jackson, S.E. Human resource management and organizational effectiveness: Yesterday and today. J. Organ. Eff. People Perform. 2014, 1, 35-55. [CrossRef] 
18. Beer, M.; Boselie, P.; Brewster, C. Back to the future: Implications for the field of hrm of the multistakeholder perspective proposed 30 years ago. Hum. Resour. Manag. 2015, 54, 427-438. [CrossRef]

19. Cohen, D.J. Hr past, present and future: A call for consistent practices and a focus on competencies. Hum. Resour. Manag. Rev. 2015, 25, 205-215. [CrossRef]

20. Stone, D.L.; Deadrick, D.L. Challenges and opportunities affecting the future of human resource management. Hum. Resour. Manag. Rev. 2015, 25, 139-145. [CrossRef]

21. Deadrick, D.L.; Gibson, P.A. Revisiting the research-practice gap in hr: A longitudinal analysis. Hum. Resour. Manag. Rev. 2009, 19, 144-153. [CrossRef]

22. Fernandez-Alles, M.; Ramos-Rodríguez, A. Intellectual structure of human resources management research: A bibliometric analysis of the journal human resource management, 1985-2005. J. Am. Soc. Inf. Sci. Technol. 2009, 60, 161-175. [CrossRef]

23. Daniels, S.R.; Wang, G.; Lawong, D.; Ferris, G.R. Collective assessment of the human resources management field: Meta-analytic needs and theory development prospects for the future. Hum. Resour. Manag. Rev. 2017, 27, 8-25. [CrossRef]

24. García Lillo, F.; Claver-Cortes, E.; Úbeda García, M.; Marco-Lajara, B.; Zaragoza Sáez, P.d.C. Mapping the "intellectual structure" of research on human resources in the "tourism and hospitality management scientific domain": Reviewing the field and shedding light on future directions. Int. J. Contemp. Hosp. Manag. 2018, 30, 1741-1768. [CrossRef]

25. Jennings, P.D.; Cyr, D.; Moore, L.F. Human resource management on the pacific rim: An integration. Hum. Resour. Manag. Pac. Rim Inst. Pract. Attitudes 1995, 351-379.

26. Le, P.C.L.; Kim, J.I.; Kim, K. The growth of korean companies and their contributions to the miracle of the han river. Int. J. Multimed. Ubiquitous Eng. 2016, 11, 253-266. [CrossRef]

27. WorldBank. Human Capital Index. Available online: https://datacatalog.worldbank.org/dataset/humancapital-index\%202018 (accessed on 18 June 2020).

28. Bae, J.; Chen, S.J.; Rowley, C. From a paternalistic model towards what? Hrm trends in korea and taiwan. Pers. Rev. 2011, 40, 700-722. [CrossRef]

29. Chang, S.-I. Study on human resource management in korea's chaebol enterprise: A case study of samsung electronics. Int. J. Hum. Resour. Manag. 2012, 23, 1436-1461. [CrossRef]

30. Kim, D.-O.; Bae, J. Employment Relations and HRM in South Korea; Taylor \& Francis: New York, NY, USA, 2017.

31. Rowley, C.; Bae, J. HRM in South Korea. In Managing Human Resources in Asia-Pacific; Budhwar, P., Varma, A., Eds.; Routledge: New York, NY, USA, 2014; pp. 31-63.

32. Tung, R.L.; Paik, Y.; Bae, J. Korean human resource management in the global context. Int. J. Hum. Resour. Manag. 2013, 24, 905-921. [CrossRef]

33. Rowley, C.; Bae, J. Globalization and transformation of human resource management in south korea. Int. J. Hum. Resour. Manag. 2002, 13, 522-549. [CrossRef]

34. Park, S.E.; Kim, Y.J. A comprehensive review on the publications of the korean journal of human resource management: 30 years achievements and prospects in the field of organization studies. J. Organ. Manag. 2010, 34, 117-151.

35. Yang, D.; Chung, S.W. Research trends for industrial relations in korea: Current and future agendas . Korean J. Manag. 2015, 23, 143-170.

36. Budhwar, P.S.; Varma, A.; Patel, C. Convergence-divergence of hrm in the asia-pacific: Context-specific analysis and future research agenda. Hum. Resour. Manag. Rev. 2016, 26, 311-326. [CrossRef]

37. KCI. Kci introduction. Available online: https://www.kci.go.kr/kciportal/main.kci?locale=en (accessed on 18 June 2020).

38. Reed, S.M. A Guide to the Human Resource Body of Knowledge (Hrbok); John Wiley \& Sons: Hobeken, NJ, USA, 2017.

39. Fleiss, J.L. Measuring nominal scale agreement among many raters. Psychol. Bull. 1971, 76, 378. [CrossRef]

40. Han, S.h.; Chae, C.; Passmore, D.L. Social network analysis and social capital in human resource development research: A practical introduction to $\mathrm{r}$ use. Hum. Resour. Dev. Q. 2019, 30, 219-243. [CrossRef]

41. Eck, N.J.v.; Waltman, L. How to normalize cooccurrence data? An analysis of some well-known similarity measures. J. Am. Soc. Inf. Sci. Technol. 2009, 60, 1635-1651. [CrossRef]

42. Waltman, L.; van Eck, N.J. A systematic empirical comparison of different approaches for normalizing citation impact indicators. J. Informetr. 2013, 7, 833-849. [CrossRef] 
43. Van Eck, N.J.; Waltman, L. Vos: A new method for visualizing similarities between objects. In Advances in Data Analysis; Springer: Berlin, Germany, 2007; pp. 299-306.

44. Borgatti, S.P.; Everett, M.G.; Johnson, J.C. Analyzing Social Networks; Sage: Thousand Oaks, Ca, USA, 2018.

45. Aria, M.; Cuccurullo, C. Bibliometrix: An r-tool for comprehensive science mapping analysis. J. Informetr. 2017, 11, 959-975. [CrossRef]

46. Csardi, G.; Nepusz, T. The igraph software package for complex network research. Interjournalcomplex Syst. 2006, 1695, 1-9.

47. Bastian, M.; Heymann, S.; Jacomy, M. Gephi: An open source software for exploring and manipulating networks. In Proceedings of the Third International AAAI Conference on Weblogs and Social Media, San Jose, CA, USA, 17-20 May 2009.

48. Jung, S.H.; Ho, Y.D.; Song, Y.S. Exploration of HRD research trends through keyword network analysis. Korean J. Hum. Resour. Dev. Q. 2014, 16, 1-33.

49. Yoo, S.; Jang, S.; Byun, S.W.; Park, S. Exploring human resource development research themes: A keyword network analysis. Hum. Resour. Dev. Q. 2019, 30, 155-174. [CrossRef]

50. Kwon, K.D.; Lee, K.W.; Lee, J. Research trends in the field of organization and HRM of local governments: Focusing on the articles published in the Korean local government studies (1989-2017). J. Local Gov. Stud. 2018, 30, 27-56. [CrossRef]

51. Chae, C.; Kim, J.; Han, S.J. Research trends in HRD(2006-2015): A keyword network analysis of articles in ahrd journals. Korean J. Hum. Resour. Dev. Q. 2017, 19, 99-127. [CrossRef]

(C) 2020 by the authors. Licensee MDPI, Basel, Switzerland. This article is an open access article distributed under the terms and conditions of the Creative Commons Attribution (CC BY) license (http://creativecommons.org/licenses/by/4.0/). 